\title{
Nanosilver: new ageless and versatile biomedical therapeutic scaffold
}

This article was published in the following Dove Press journal:

International Journal of Nanomedicine

\author{
Shahid Ullah Khan, ${ }^{1,2}$ Tawfik \\ A Saleh, ${ }^{3}$ Abdul Wahab, ${ }^{4}$ \\ Muhammad Hafeez Ullah \\ Khan, ${ }^{1,2}$ Dilfaraz Khan, ${ }^{5}$ \\ Wasim Ullah Khan, ${ }^{6}$ Abdur \\ Rahim, ${ }^{7}$ Sajid Kamal, ${ }^{8}$ \\ Farman Ullah Khan, ${ }^{9}$ Shah \\ Fahad $^{1,10}$ \\ 'College of Plant Sciences and \\ Technology, ${ }^{2}$ National Key Laboratory \\ of Crop Genetics Improvement, \\ Huazhong Agricultural University, \\ Wuhan, People's Republic of China; \\ ${ }^{3}$ Department of Chemistry, King Fahd \\ University of Petroleum \& Minerals, \\ Dhahran, Saudi Arabia; ${ }^{4}$ Department \\ of Pharmacy, Kohat University of \\ Science and Technology, Kohat, \\ ${ }^{5}$ Institute of Chemical Sciences, Gomal \\ University, Dera Ismail Khan, Pakistan; \\ ${ }^{6} \mathrm{~S} c h o o l$ of Chemistry and Chemical \\ Engineering, Sun Yat-Sen University, \\ Guangzhou, People's Republic of \\ China; Interdisciplinary Research \\ Centre in Biomedical Materials \\ (IRCBM), COMSATS Institute of \\ Information Technology, Lahore, \\ Pakistan; ${ }^{8}$ School of Biotechnology, \\ Jiangnan University, Wuxi, People's \\ Republic of China; ${ }^{9}$ Department of \\ Chemistry, University of Science and \\ Technology, Bannu, ${ }^{10}$ Department \\ of Agriculture, University of Swabi, \\ Swabi, Pakistan
}

Correspondence: Abdul Wahab Department of Pharmacy, Kohat University of Science and Technology, Kohat, Khyber Pakhtunkhwa, Pakistan Email wahabscholar@yahoo.com

Tawfik A Saleh

Department of Chemistry, King Fahd University of Petroleum \& Minerals, Dhahran 3|26I, Saudi Arabia Email tawfikas@hotmail.com

\begin{abstract}
Silver nanotechnology has received tremendous attention in recent years, owing to its wide range of applications in various fields and its intrinsic therapeutic properties. In this review, an attempt is made to critically evaluate the chemical, physical, and biological synthesis of silver nanoparticles (AgNPs) as well as their efficacy in the field of theranostics including microbiology and parasitology. Moreover, an outlook is also provided regarding the performance of AgNPs against different biological systems such as bacteria, fungi, viruses, and parasites (leishmanial and malarial parasites) in curing certain fatal human diseases, with a special focus on cancer. The mechanism of action of AgNPs in different biological systems still remains enigmatic. Here, due to limited available literature, we only focused on AgNPs mechanism in biological systems including human (wound healing and apoptosis), bacteria, and viruses which may open new windows for future research to ensure the versatile application of AgNPs in cosmetics, electronics, and medical fields.
\end{abstract}

Keywords: synthesis of AgNPs, theranostics, antimicrobial properties, biomedical applications of AgNPs

\section{Introduction}

"Nano" is a Greek word meaning small or dwarf. Nanoparticles can be defined as the particles ranging in size from 1 to $100 \mathrm{~nm}$ in either direction but can be considered as ranging up to several hundred nanometers. ${ }^{1}$ These are actually aggregates of atoms, ions, or molecules. ${ }^{1}$ In other words, "nano" is used to represent one billion of a meter or can be referred to as $10^{-9} \mathrm{~m}$. The concept of nanotechnology was first defined by Professor Norio Taniguchi in 1974, and since then, the field of nanotechnology has been receiving immense attention, especially from the early $1980 \mathrm{~s}^{2,3}$

Various terminologies are used for silver particles such as colloidal silver, nanosilver, silver nanostructures, and silver nanoparticles (AgNPs). For the sake of convenience, we use the abbreviation AgNPs throughout this review. Nanotechnology is an advanced field dealing with the manufacturing of different kinds of nanomaterials having biomedical applications. ${ }^{4}$ Due to a wide range of transmittable diseases caused by different pathogenic bacteria and their enhanced antibiotic resistance, many pharmaceutical companies and researchers are striving for synthesizing novel materials with enhanced antibacterial activity and reduced side effects. Currently, nanoscale materials have achieved considerable attention as novel antimicrobial agents due to their high surface area-to-volume ratio and distinct physical and chemical properties. ${ }^{5-7}$ The extremely strong broad-spectrum antimicrobial property of AgNPs is the key direction for the improvement of AgNPs-based biomedical products, including bandages, catheters, antiseptic sprayers, textiles, and food storage containers. ${ }^{8}$ 
Currently, different metals including zinc, titanium and copper, ${ }^{9}$ magnesium and gold, ${ }^{10,11}$ and alginate ${ }^{12}$ are used as antimicrobial agents, but among these AgNPs have been found to be the most efficient due to their outstanding antimicrobial properties. ${ }^{13}$ In particular, nanosilver has been verified to have a great medicinal value attributable to its characteristic antibacterial, ${ }^{13,14}$ antifungal, ${ }^{9}$ antiviral, ${ }^{15}$ antiprotozoal, ${ }^{16}$ anticatalytic, ${ }^{17}$ and antiarthropodal characteristics. ${ }^{18}$ In cancer, metastasis is a great challenge to oncologists and clinicians due to the development of resistance to anticancer agents, ${ }^{19}$ however, this problem can be overcome by nanoscale materials, especially nanosilver.

Nowadays, the applications of nanoparticles are tremendously increasing as they possess unique optical, chemical, electrical, electronic, and mechanical properties. These properties are attributed to their large surface area-to-volume ratio, which imparts them unique properties as compared to atoms/molecules as well as the bulk of the same material. Metallic particles, specifically AgNPs, are in focus due to their antimicrobial resistance as metal ions, while antibiotics are losing their effectiveness due to development of resistant strains of microbes. ${ }^{1}$ Although the antimicrobial properties of AgNPs are extensively studied, their activities against other types of pathogens such as arthropods and different types of cancer cells have been evaluated only recently. AgNPs as therapeutic agents have achieved remarkable attention in the treatment of cancer, leishmania, malaria, and many other human diseases. However, there still remain many questions that are a matter of discussion for future research.

The focus of this review is to provide a comprehensive, well-elaborated, and up-to-date view about what is currently investigated about the antimicrobial and antiparasitic activities and various methods used for the synthesis of AgNPs. Besides, we strive to compile all the most recent investigations about the applications of AgNPs in many fields with a special focus on cancer and viral infection inhibition, and the toxicology of AgNPs. We strongly believe that this review will provide a handy mechanistic framework for the future analysis of AgNPs.

\section{Methods for the synthesis of nanosilver}

AgNPs can be synthesized by various methods (Figure 1) including chemical synthesis, ${ }^{8,20-22}$ physical techniques, ${ }^{8,22,23}$ and green or biological methods. ${ }^{24-26}$ Some important examples for biological, physical, and chemical synthesis of AgNPs are mentioned in Table 1.

\section{Silver nanostructure prepared by chemical methods}

AgNPs can be synthesized by chemical reduction, ${ }^{92}$ electrochemical technique, ${ }^{20}$ irradiation-assisted chemical method, ${ }^{93}$ and pyrolysis; ${ }^{21}$ of these, chemical reduction has been the most common route to synthesize nanosilver. Three main components, namely organic and inorganic reducing agents, capping agents or stabilizers, and metal precursors or silver salts, are used in this method (Figure 2). Hydrogen gas, ${ }^{94}$ borohydride, ${ }^{80,94,95}$ citrate, ${ }^{96}$ ascorbic acid, ${ }^{97}$ hydrazine compounds, polyol process, Tollens' reagent, $N, N$-dimethylformamide, and poly (ethylene glycol) (PEG)block polymers are the reducing agents most frequently used in this method. These reductants bring about a reduction of silver ions $\left(\mathrm{Ag}^{+}\right)$to metallic silver $\left(\mathrm{Ag}^{0}\right)$ followed by agglomeration into oligomeric clusters in aqueous and nonaqueous solutions. Finally, these clusters form metallic colloidal nanosilver. ${ }^{98-100}$ Borohydride has been extensively used for reduction process because of its strong and rapid reductant properties as well as its ability to act as a stabilizer to evade aggregation of AgNPs throughout decaying. ${ }^{94}$

The commonly reported stabilizing/capping agents include surfactants and polymeric compounds such as polyvinyl pyrrolidone (PVP), PEG, poly( $N$-isopropylacrylamide), poly (methyl methacrylate), poly (methacrylic acid), and collagen. ${ }^{101,102}$ Among these stabilizers, the alcohols, thiols, amines, acidic functional groups, and surfactants protect the nanoparticles from sedimentation as well as protect them from losing their surface properties. Silver nitrate $\left(\mathrm{AgNO}_{3}\right)$ is the most significant silver salt frequently used for the preparation of AgNPs, and as compared to other salts, it is chemically stable, easily available, and cost-effective. ${ }^{103}$ A detailed summary of reducing, capping, or stabilizing agents and silver salts or metal precursors used in biological, chemical, and physical methods is provided in Table 2.

In their recent study, Zhang et al reported that colloidal silver could be synthesized through the chemical reaction of polymethylene bisacrylamide aminoethyl piperazine with terminal dimethylamine groups (HPAMAM-N $\left(\mathrm{CH}_{3}\right)_{2}$ ). Later on, it was documented that these groups have strong reducing and stabilizing potential. ${ }^{104}$ In another case study, it was demonstrated that polyol process and modified injection technique could produce spherical, highly mono-dispersed AgNPs of controllable size. The reaction temperature and rate of injection were important factors in this method to obtain uniform AgNPs of reduced sized. AgNPs with $17 \pm 2 \mathrm{~nm}$ diameter were obtained at $100^{\circ} \mathrm{C}$ and $2.5 \mathrm{~mL} / \mathrm{s}$ injection rate. ${ }^{73}$ 

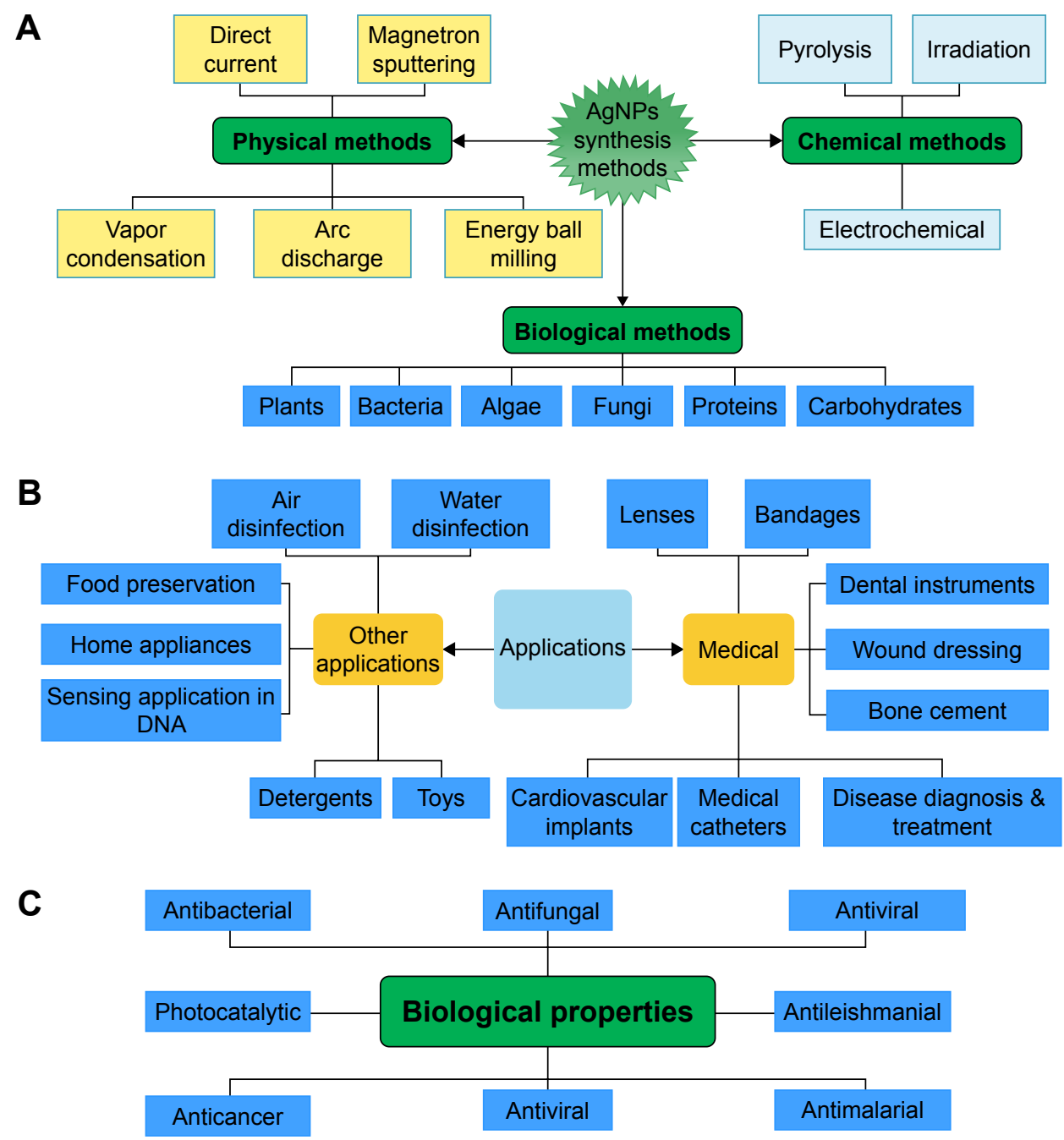

Figure I Overall view of $(\mathbf{A})$ synthesis methods, (B) biological properties, and (C) biomedical applications and toxicity of AgNPs. Abbreviation: AgNPs, silver nanoparticles.

Similar to chemical reduction method, the silver nanostructure can be synthesized by an electrochemical method. Using this approach, small-sized (10-20 nm) AgNPs with spherical shape can be produced. ${ }^{78}$ Furthermore, using crystals of zeolite, monodisperse silver nanospheroids of size $1-18 \mathrm{~nm}$ have been formed by electrochemical reduction. ${ }^{105}$ However, using organic and aqueous interface, polyphenylpyrrole-coated silver nanospheroids of size 3-20 nm can be obtained by electrochemical method..$^{77}$

Irradiation is another method to prepare AgNPs. Abid et al concluded from their study that AgNPs of definite shape and size can be produced using laser irradiation of surfactant and an aqueous solution of silver salt. ${ }^{106}$ Sudeep and Kamat successfully induced the synthesis of AgNPs in ethanol/ toluene organic solution. ${ }^{107}$ However, more investigations are needed to further address the possible in vitro and in vivo potential toxicities that can be the outcomes of the chemical method used for synthesizing AgNPs.

\section{AgNPs preparation by physical methods}

The most important physical techniques frequently used for the preparation of AgNPs include evaporation/vapor condensation, ${ }^{22,102,108}$ arc discharge, ${ }^{109}$ energy ball milling, ${ }^{110}$ and direct current magnetron sputtering method. ${ }^{23}$ Compared to chemical methods, physical methods are generally less time consuming and do not involve any type of hazardous chemicals. ${ }^{110}$ However, high energy consumption and requirement of long time for thermal stability are still the bottlenecks of these methods. ${ }^{22,111,112}$

Tsuji et al used the small ceramic heater and laser ablation method, respectively, to synthesize AgNPs. ${ }^{116}$ Later on, investigators successfully synthesized colloidal AgNPs in a 
Table I Biologically, physically, and chemically synthesized AgNPs

Methods and organisms/ Shape Size (nm) Reference
process used

\section{Biological}

Bacteria

$\begin{array}{llll}\text { Acinetobacter calcoaceticus } & \text { Spherical } & 8-12 & 27 \\ \text { Enterobacter aerogenes } & \text { Spherical } & 25-35 & 28 \\ \text { Klebsiella pneumoniae } & \text { Spherical } & 15-37 & 29 \\ \begin{array}{l}\text { Proteus mirabilis } \\ \text { Shewanella oneidensis }\end{array} & \text { Spherical } & 10-20 & 30 \\ \text { MR-I } & \text { Spherical } & 2-16 & 31 \\ \begin{array}{l}\text { Stenotrophomonas } \\ \text { maltophilia }\end{array} & \text { Cuboidal } & 93 & 32 \\ \text { Vibrio alginolyticus } & & & \\ \begin{array}{l}\text { Bacillus licheniformis } \\ \text { Brevibacterium casei }\end{array} & \text { Spherical } & 50-100 & 33 \\ \begin{array}{l}\text { Exiguobacterium spp. } \\ \text { Rhodococcus spp. }\end{array} & \text { Spherical } & 50 & 34 \\ \text { Thermoactinomyces spp. } & \text { Spherical } & 5-50 & 35 \\ \text { Bacillus thuringiensis } & \text { Spherical } & 10-15 & 36 \\ \text { Plants } & \text { ND } & 40-40 & 37 \\ \text { Chenopodium murale } & \text { ND } & 30-52-142.97 & 39 \\ \text { Fraxinus excelsior } & \text { Spherical } & 25-40 & 40 \\ \text { Moringa oleifera } & \text { Spherical } & 100 & 42 \\ \text { Hypnea musciformis } & \text { Cubic } & 40-60 & 43 \\ \text { Nyctanthes arbortristis } & \text { Spherical and } & 5-20 & 44 \\ & \text { oval } & & \\ \text { Turmeric } & \text { Spherical } & 5-10 & 45\end{array}$

Turmeric

Lantana camara

Jasminum nervosum

Psidium guajava

Saraca indica

Leucas aspera

Dalbergia spinosa

Melia dubia

Citrus sinensis

Chrysanthemum indicum

Acacia leucophloea

Aegle marmelos

Alpinia galanga

Antigonon leptopus

Artemisia princeps

Caesalpinia coriaria

Cassia auriculat

Fungi

Penicillium expansum

Aspergillus terreus

Fusarium oxysporum

Cryphonectria spp.

Cochliobolus lunatus

Fusarium culmorum

Pestalotia spp.

Phoma glomerata

Aspergillus niger

Algae

Spherical 5-10 45

ND $\quad$ II-24 46

Spherical $\quad 9.4 \quad 47$

Spherical $\quad 26 \quad 48$

Spherical $22 \quad 49$

Spherical 25-80 50

Spherical $18 \quad 51$

Spherical $\quad 30-50 \quad 51$

Spherical $7.36 \quad 52$

Spherical 37.7I-7I.99 53

Spherical 17-29 54

Spherical $\quad 34.7 \quad 55$

Spherical $20.82 \quad 56$

Spherical 10-60 $\quad 57$

Spherical $\quad 10-40 \quad 58$

Triangle, $\quad 40-98 \quad 59$

hexagonal,

and spherical

Spherical 20

Spherical 34

60

61

ND $\quad 14$ and $25 \quad 62$

ND $\quad 10-18 \quad 62$

Spherical $\quad 40.3 \pm 3.5 \quad 63$

Spherical $\quad 30-70 \quad 64$

Spherical 3-21 65

Spherical 5-25 66

Spherical $\quad 10-40 \quad 67$

Spherical $\quad 60-80 \quad 68$

Spherical $\quad 03-30 \quad 69$

Spirulina platensis
Spherical $\quad 07-16 \quad 70$
Table I (Continued)

\begin{tabular}{|c|c|c|c|}
\hline $\begin{array}{l}\text { Methods and organisms/ } \\
\text { process used }\end{array}$ & Shape & Size $(\mathrm{nm})$ & $\overline{\text { Reference }}$ \\
\hline \multicolumn{4}{|l|}{ Physical } \\
\hline Using arc discharge & ND & 10 & 71 \\
\hline By laser ablation & ND & $20-50$ & 72 \\
\hline $\begin{array}{l}\text { By physical deposition of } \\
\text { metal }\end{array}$ & Round & 3.5 & 73 \\
\hline $\begin{array}{l}\text { Using electrical arc } \\
\text { discharge }\end{array}$ & Nanospheres & $\sim 10$ & 74 \\
\hline $\begin{array}{l}\text { Using electrical arc } \\
\text { discharge }\end{array}$ & Nanospheres & $14-27$ & 73 \\
\hline \multicolumn{4}{|l|}{ Chemical } \\
\hline By photoinduced method & Triangle & $30-120$ & 76 \\
\hline Using UV light irradiation & ND & $02-08$ & 77 \\
\hline By electrochemical & ND & $03-20$ & 78 \\
\hline reduction & & & \\
\hline $\begin{array}{l}\text { Using electrochemical } \\
\text { method }\end{array}$ & Spherical & $10-20$ & 79 \\
\hline Using plasma gas & Spherical & $10-80$ & 80 \\
\hline
\end{tabular}

Abbreviations: AgNPs, silver nanoparticles; ND, not detected; UV, ultraviolet.

metal solution with no chemical reagent added. Furthermore, using arc discharge method, Tien et al produced AgNPs having $20-30 \mathrm{~nm}$ size in pure water without the addition of any stabilizers or surfactants. ${ }^{103}$

Some studies documented that AgNPs were formed when bulk materials in solution were subjected to laser ablation technique..$^{22,113-115}$ Meanwhile, it was also found that silver nanospheroids sized $20-50 \mathrm{~nm}$ can be obtained by the same technique in pure water with femtosecond laser pulses at $800 \mathrm{~nm} .{ }^{71}$ Laser ablation method has an advantage over other techniques because there is no need to add any reagent to solutions. Thus, laser ablation technique is useful for the production of uncontaminated and pure metal colloids. ${ }^{116}$

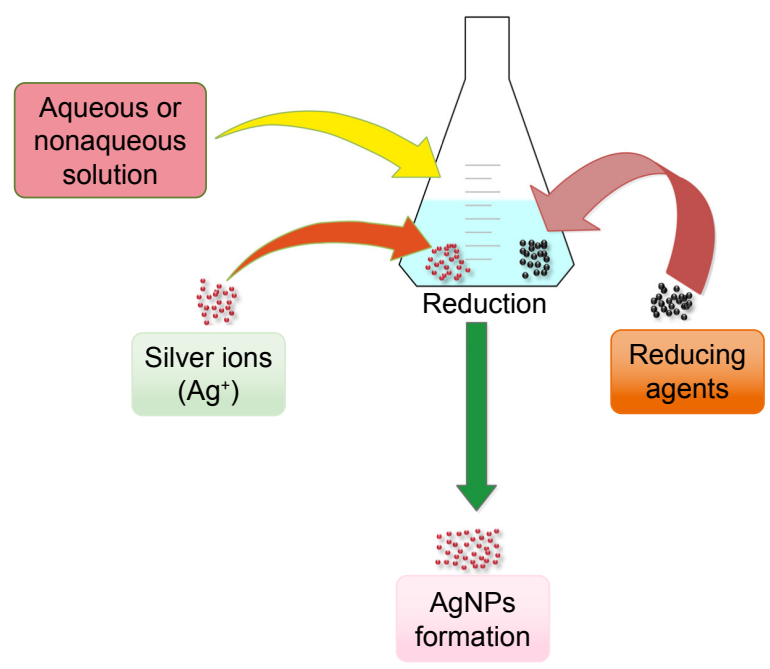

Figure 2 Chemical synthesis of AgNPs.

Abbreviation: AgNPs, silver nanoparticles. 
Table 2 Widely used reducing agents, metal precursors/salts, and capping/stabilizing agents in AgNPs synthesis

\begin{tabular}{|c|c|c|c|}
\hline Methods & Common reductants or reducing agents & $\begin{array}{l}\text { Important metal } \\
\text { precursors/salts }\end{array}$ & Stabilizing/capping agents \\
\hline \multirow[t]{8}{*}{ Biological } & Proteins & $\mathrm{AgNO}_{3}$ & Proteins \\
\hline & Peptides & $\mathrm{Ag}_{2} \mathrm{~S}$ & Peptides \\
\hline & Carbohydrates & $\mathrm{Ag}_{2} \mathrm{O}$ & Carbohydrates \\
\hline & Bacteria & & Bacteria \\
\hline & Fungi & & Fungi \\
\hline & Yeast & & Yeast \\
\hline & Algae & & Algae \\
\hline & Plants & & Plants \\
\hline \multirow[t]{13}{*}{ Chemical } & Sodium citrate $\left(\mathrm{Na}_{3} \mathrm{C}_{6} \mathrm{H}_{5} \mathrm{O}_{7}\right)$ & $\mathrm{AgNO}_{3}$ & Polyvinyl pyrrolidone $\left(\left(\mathrm{C}_{6} \mathrm{H}_{9} \mathrm{NO}\right)_{\mathrm{n}}\right)$ \\
\hline & Ascorbic acid $\left(\mathrm{C}_{6} \mathrm{H}_{8} \mathrm{O}_{6}\right)$ & $\mathrm{AgClO}_{4}$ & Poly (ethylene glycol) $\left(\mathrm{C}_{2 n} \mathrm{H}_{4 n+2} \mathrm{O}_{n+1}\right)$ \\
\hline & Sodium borohydride $\left(\mathrm{NaBH}_{4}\right)$ & $\mathrm{Ag}_{2} \mathrm{SO}_{4}$ & Poly (methacrylic acid) $\left(\left(\mathrm{C}_{4} \mathrm{H}_{6} \mathrm{O}_{2}\right)_{\mathrm{n}}\right)$ \\
\hline & Hydrogen gas $\left(\mathrm{H}_{2}\right)$ & & Poly (methyl methacrylate) $\left(\left(\mathrm{C}_{5} \mathrm{H}_{8} \mathrm{O}_{2}\right)_{\mathrm{n}}\right)$ \\
\hline & Tollens' reagent $\left(\mathrm{Ag}\left(\mathrm{NH}_{3}\right)_{2} \mathrm{NO}_{3}\right)$ & & Poly $(\mathrm{N}$-isopropylacrylamide $)\left(\left(\mathrm{C}_{6} \mathrm{H}_{11} \mathrm{NO}\right)_{n}\right)$ \\
\hline & $\mathrm{N}, \mathrm{N}$-Dimethylformamide $\left(\mathrm{C}_{3} \mathrm{H}_{7} \mathrm{NO}\right)$ & & Collagen \\
\hline & Poly (ethylene glycol)-block copolymers $\left(\mathrm{C}_{2 \mathrm{n}} \mathrm{H}_{4 n+2} \mathrm{O}_{n+1}\right)$ & & Trisodium citrate $\left(\mathrm{Na}_{3} \mathrm{C}_{6} \mathrm{H}_{5} \mathrm{O}_{7}\right)$ \\
\hline & Dextrose $\left(\mathrm{C}_{6} \mathrm{H}_{12} \mathrm{O}_{6}\right)$ & & Dodecanoic acid $\left(\mathrm{C}_{12} \mathrm{H}_{24} \mathrm{O}_{2}\right)$ \\
\hline & Hydrazine compounds $\left(\mathrm{N}_{2} \mathrm{H}_{4}\right)$ & & Oleylamine $\left(\mathrm{C}_{18} \mathrm{H}_{35} \mathrm{NH}_{2}\right)$ \\
\hline & $\beta$-D-Glucose $\left(\mathrm{C}_{6} \mathrm{H}_{12} \mathrm{O}_{6}\right)$ & & Gluconic acid $\left(\mathrm{C}_{6} \mathrm{H}_{12} \mathrm{O}_{7}\right)$ \\
\hline & m-Hydroxy benzaldehyde $\left(\mathrm{C}_{7} \mathrm{H}_{6} \mathrm{O}_{2}\right)$ & & Carboxymethylated chitosan \\
\hline & Carboxymethylated chitosan & & Sodium dodecyl sulfate $\left(\mathrm{NaC}_{12} \mathrm{H}_{25} \mathrm{SO}_{4}\right)$ \\
\hline & Alcohols (R-OH) & & $\mathrm{Bis}$ (2-ethylhexyl) sulfosuccinate (AOT) $\left(\mathrm{C}_{20} \mathrm{H}_{37} \mathrm{NaO}_{7} \mathrm{~S}\right)$ \\
\hline Physical & Electric arc discharge and water & $\mathrm{Ag}$ wires and $\mathrm{AgNO}_{3}$ & Sodium citrate $\left(\mathrm{Na}_{3} \mathrm{C}_{6} \mathrm{H}_{5} \mathrm{O}_{7}\right)$ \\
\hline
\end{tabular}

Abbreviation: AgNPs, silver nanoparticles.

\section{UV-initiated photoreduction}

A simple and effective method, ultraviolet (UV)-initiated photoreduction, has been reported for the synthesis of AgNPs in the presence of citrate, PVP, poly (acrylic acid), and collagen. For instance, Huang and Yang produced AgNPs via photoreduction of $\mathrm{AgNO}_{3}$ in layered inorganic laponite clay suspension which served as a stabilizing agent for the prevention of NPs aggregation. The properties of produced NPs were studied as a function of UV irradiation time. Bimodal size distribution and relatively large AgNPs were obtained using UV irradiation for $3 \mathrm{~h}$. Further irradiation disintegrated the AgNPs into smaller-sized particles with a single distribution mode until a relatively stable size and size distribution were obtained. ${ }^{117}$ Silver NPs (nanosphere, nanowire, and dendrite) have been prepared by UV irradiation photoreduction technique at room temperature using poly (vinyl alcohol) (PVA) (as protecting and stabilizing agent). The concentration of both PVA and $\mathrm{AgNO}_{3}$ played a significant role in the growth of the nanorods and dendrites. ${ }^{118}$

Previous studies demonstrated that UV light can assist in the reduction of silver ions to immobilize AgNPs on the surface of the polymer. Synthesis approach was applied to immobilize AgNPs in situ on the surface of sericin gel with the assistance of UV light. Scanning electron microscopy (SEM), X-ray diffractometry, Fourier-transform infrared spectroscopy, and differential scanning calorimetry were applied to characterize the surface tomography and structure of the AgNPs-modified sericin materials. Sericin gel was cut into small sheets and then soaked into $50 \mathrm{mM} \mathrm{AgNO}_{3}$ solution. At the same time, sericin gel sheets were irradiated with a $365 \mathrm{~nm}$ UV light lamp ( $24 \mathrm{~W}$ ) for 10, 30, and 60 min to make AgNPs immobilize on the surface of sericin gel, respectively. The collected AgNPs-modified sericin gel sheets were dried at room temperature, and then their surface tomography, structure, and antimicrobial activity were studied. ${ }^{119}$

The sonoelectrochemistry technique utilizes the ultrasonic power primarily to manipulate the material mechanically. The pulsed sonoelectrochemical synthetic method involves alternating sonic and electric pulses. Electrolyte composition plays a crucial role in shape formation. ${ }^{120}$ It was reported that silver nanospheres could be prepared by sonoelectrochemical reduction using a complexing agent, nitrilotriacetate, to avoid aggregation. ${ }^{120}$

\section{Silver nanostructure synthesis using biological systems}

The bio-based or green synthesis of AgNPs has great advantages over chemical and physical methods. Biologically synthesized AgNPs are eco-friendly, as no toxic reductants or stabilizing agents are used during the synthesis of nanoparticles. 
In biological systems, the health hazardous reducing and stabilizing agents can be substituted by essential biomolecules such as proteins ${ }^{121}$ and carbohydrates, ${ }^{122}$ which are locally produced by microbes including bacteria, ${ }^{23,123-125}$ fungi ${ }^{24,62,126,127}$ and yeast, ${ }^{127-129}$ plants, ${ }^{25,127,130,131}$ and lower organisms like algae. ${ }^{127,130,131}$ The different reducing, capping, or stabilizing agents and silver salts or metal precursors which are used during biological method are presented in Table 2. Herein, we summarize some important biogenic synthesis or biological systems such as plants, bacteria, fungi, and algae using proteins and polysaccharides as reducing and stabilizing agents for the synthesis of AgNPs.

\section{Plants}

Plant-based production is one of the most cost-effective and valuable alternative large-scale method for synthesizing AgNPs. ${ }^{132}$ Researchers have put attempts and focused to synthesize AgNPs of varying size and shape using different plant extracts with a broad range of antimicrobial, anticancer, antiviral, and anticatalytic activities as shown in Table 3. Euphorbia hirta leaf extract was used for the synthesis of AgNPs resulting in the production of spherical nanoparticles sized 40-50 nm. These AgNPs showed strong activity against Bacillus cereus and Staphylococcus aureus bacterial strains. ${ }^{133}$ Krishnaraj et al and Veerasamy et al were able to synthesize AgNPs of size 20-30 and $35 \mathrm{~nm}$, respectively, using leaf extracts of the medicinal plants Acalypha indica and Garcinia mangostana. ${ }^{134,135}$

In a recent study, the leaf extract of Ocimum sanctum was found to reduce $\mathrm{Ag}^{+}$ions into crystalline AgNPs having a size of 4-30 $\mathrm{nm}$ in $8 \mathrm{~min}$. However, due to the presence of ascorbic acid in the plant leaves, the silver ions were readily reduced to metallic silver. The authors related the stability of the particles to the presence of proteins which played an important role as capping agents. The resulted AgNPs were effective against Escherichia coli and S. aureus. ${ }^{136}$

The cubic- and hexagonal-shaped AgNPs of 31-40 nm size were obtained using the bark extract of Cinnamon zeylanicum. ${ }^{137}$ Spherically shaped nanosilver sized $1-10 \mathrm{~nm}$ was synthesized from geraniol $\left(\mathrm{C}_{10} \mathrm{H}_{18} \mathrm{O}\right)$ compound isolated from two important medicinal plants, namely Pelargonium graveolens and Azadirachta indica. These AgNPs ablated fibrosarcoma Wehi 164 cancer cells. ${ }^{86}$ In another study, ten different Cassia medicinal plant species were screened for the biosynthesis of AgNPs. It was also found that the leaves of $P$. graveolens and Cinnamomum camphora contained

Table 3 Biological properties of phytogenic AgNPs

\begin{tabular}{|c|c|c|c|c|c|}
\hline Plants name & Part used & Shape of AgNPs & $\begin{array}{l}\text { Size of } \\
\text { AgNPs (nm) }\end{array}$ & Biological properties & Reference \\
\hline Caesalpinia coriaria & Leaf & $\begin{array}{l}\text { Spherical, triangle, and } \\
\text { hexagonal }\end{array}$ & 40-98 & Antibacterial & 81 \\
\hline Chenopodium murale & Leaf & ND & $30-35$ & Antibacterial & 40 \\
\hline Chrysanthemum indicum & Flowers & Spherical & $37.7 I-71.99$ & Antibacterial & 53 \\
\hline Dalbergia spinosa & Leaves & Spherical & 18 & $\begin{array}{l}\text { Antibacterial, antioxidant, } \\
\text { and anti-inflammatory }\end{array}$ & 51 \\
\hline Melia dubia & Leaf & ND & $30-50$ & Antibacterial and larvicidal & 82 \\
\hline Azadirachta indica & Leaf & Hexagonal and spherical & 200 & Antibacterial & 83 \\
\hline Andrographis paniculata & Leaf & Cubic & $40-60$ & Antibacterial & 84 \\
\hline Acacia leucophloea & Bark & Spherical & $17-29$ & Antibacterial & 54 \\
\hline Chrysanthemum indicum & Flowers & Spherical & $37.71-71.99$ & Cytotoxicity & 53 \\
\hline Aegle marmelos & Fruit & Spherical & 34.7 & Antibacterial & 55 \\
\hline Alpinia galanga & Rhizome & Spherical & 20.82 & Antifungal and antibacterial & 56 \\
\hline Lantana camara & Leaf & ND & II-24 & Antibacterial & 46 \\
\hline Moringa oleifera & Leaf & Spherical & 100 & Antibacterial & 85 \\
\hline Pelargonium graveolens & & Spherical & 6 & Anticancer & 86 \\
\hline Psidium guajava & Leaves and fruit & Spherical & 60 and 26 & Antifungal and antibacterial & 48,87 \\
\hline Turmeric & Root & Spherical & $5-10$ & Antioxidant & 45 \\
\hline Morinda citrifolia & Root & ND & $32-55$ & Anticancer & 88 \\
\hline Fraxinus excelsior & Leaf & Spherical & $25-40$ & Antioxidant & $4 I$ \\
\hline Ficus carica & Latex & Spherical & 163.7 & Antioxidant & 89 \\
\hline Euphorbia nivulia & Stem latex & Spherical & $<100$ & Anticancer & 90 \\
\hline Cassia auriculata & Leaf & Spherical & 20 & Anticancer & 60 \\
\hline Artemisia princeps & Leaf & Spherical & $10-40$ & Anticancer and antibacterial & 58 \\
\hline Alternanthera sessilis & Leaf & Spherical & 32.81 & Anticancer & 58 \\
\hline Albizia adianthifolia & Leaf & Spherical & $4-35$ & Anticancer & 91 \\
\hline
\end{tabular}

Abbreviations: AgNPs, silver nanoparticles; ND, not detected. 
terpenoids which were responsible for the biosynthesis of AgNPs. ${ }^{130,138}$ Among them, only the aqueous leaf extract of Cassia roxburghii supported the synthesis of stable AgNPs ( $35 \mathrm{~nm}$ size). These nanoparticles were further tested against human and plant pathogenic fungi, and they exhibited excellent result as compared to tested standard drugs. ${ }^{139}$

Chandran et $\mathrm{al}^{140}$ and $\mathrm{Li}$ et $\mathrm{al}^{141}$ reported the synthesis of AgNPs from the leaf extracts of Aloe vera and Capsicum annum plants, respectively. The rapid synthesis of AgNPs using the fruit extract of Carica papaya was demonstrated, and it was found that the synthesized nanoparticles were highly toxic against different multidrug-resistant (MDR) human pathogens. ${ }^{142}$ Begum et $\mathrm{al}^{143}$ were able to synthesize stable AgNPs of various shapes using black tea leaf extract. Extracellular synthesis of AgNPs was also carried out using leaf extract of Pine, Persimmon, Ginkgo, Magnolia, and Platanus plants. ${ }^{144}$ In addition, AgNPs were successfully synthesized using the latex and seed extract of Jatropha curcas. ${ }^{145}$ The compatibility of the bark and powder extracts of Curcuma longa was also checked towards the formation of AgNPs, and it was reported that bark extract could produce a higher amount of AgNPs compared to the powder extract. ${ }^{146}$

Babu and Prabu described the AgNP synthesis using a leaf extract of $C$. camphora, while the reduction was considered to be due to presence of the phenolics, terpenoids, polysaccharides, and flavonoids in the extract. ${ }^{147}$

A simple, environmental-friendly, and cost-effective method has been developed to synthesize AgNPs using tea leaf extract. The synthesized AgNPs showed a good stability in terms of time-dependent release of silver ions. Due to the larger size and less silver ion release, the synthesized NPs showed low antibacterial activity against E. coli. ${ }^{148}$

The biosynthesis of AgNPs was reported for the first time using identified antimicrobial molecules (gallic acid + apocynin) and (gallic acid + apocynin + quercetin) from the medicinal plant Pelargonium endlicherianum Fenzl., and these AgNPs had dramatically enhanced antimicrobial activity. ${ }^{149}$

\section{Bacteria}

Klaus et al were the first to explore the ability of the bacterium Pseudomonas stutzeri AG259 to synthesize AgNPs. The bacteria exhibited a remarkable property of surviving in an extreme silver-rich environment, which might be the possible explanation for the accumulation of nanosilver. ${ }^{150}$ Nanosilver particles have been synthesized using both Gram-positive and Gram-negative bacteria including the silver-resistant bacteria to form AgNPs. ${ }^{151}$ Some bacteria have the ability to produce extracellular AgNPs, while others can synthesize intracellular
AgNPs. Interestingly, some bacteria including Calothrix pulvinata, Anabaena flos-aquae, ${ }^{152}$ Vibrio alginolyticus, ${ }^{33}$ Aeromonas spp. SH10, ${ }^{153}$ Plectonema boryanum UTEX $485,{ }^{154}$ and Lactobacillus spp. ${ }^{155}$ have the ability to produce both extra- and intracellular AgNPs.

Like other methods, metal precursors or silver salts are also used in the preparation of silver nanostructure from bacterial cultures. The production of AgNPs using sulfide $\left(\mathrm{Ag}_{2} \mathrm{~S}\right)$ and oxide $\left(\mathrm{Ag}_{2} \mathrm{O}\right)$ of silver has also been reported by various studies. ${ }^{31,156}$ In a recent report, the culture supernatant of bacterium Bacillus licheniformis was used to produce 40 and $50 \mathrm{~nm}$ AgNPs, respectively. ${ }^{157,158}$ AgNPs of 1-6 nm size has also been produced using visible light emission from the supernatants of Klebsiella pneumoniae. ${ }^{159}$ Furthermore, it was also found that Lactobacillus strains can be used for the production of AgNPs. ${ }^{155,160}$ Recently, the bacterial strains of Aeromonas spp. SH10 and Corynebacterium spp. SH09 were screened for the biosynthesis of AgNPs. The authors concluded from their results that the bio-reduction of $\left[\mathrm{Ag}\left(\mathrm{NH}_{3}\right)_{2}\right]^{+}$resulted in the production of monodispersed and stable AgNPs. ${ }^{153}$

\section{Fungi}

Green and/or biogenic synthesis of any type of nanoparticles involves natural processes occurring in microorganisms like fungi, bacteria, and plants, as shown in Figure 3. These organisms generate biocompatible nanostructures having excellent therapeutic potential. ${ }^{131}$ Fungi-based synthesis of AgNPs is also eco-friendly and of low cost. In a recent study, two fungal strains, namely Penicillium expansum $\mathrm{HA} 2 \mathrm{~N}$ and Aspergillus terreus HA1N, were reported for the synthesis of AgNPs. The transmission electron microscopy result showed that $14-25 \mathrm{~nm}$ AgNPs were obtained from $P$. expansum, while 10-18 nm AgNPs were obtained from A. terreus. The efficacy of these AgNPs was further examined against different fungal species which demonstrated their strong antifungal potential. ${ }^{62}$

Recent studies showed that AgNPs of size 5-25 and 5-50 nm could be extracellularly synthesized using Aspergillus fumigatus and Fusarium oxysporum, respectively. ${ }^{161,162}$ The authors further reported that most of the nanoparticles were spherical in shape; however, rare triangular-shaped nanoparticles were also noticed. ${ }^{161}$

Balaji et al used an extracellular solution of Cladosporium cladosporiodes for the reduction of $\mathrm{AgNO}_{3}$ to form sphericalshaped AgNPs of 10-100 nm size. They further reported that $C$. cladosporiodes released some organic materials, including polysaccharides, organic acids, and proteins, which were responsible for the formation of spherical crystalline 


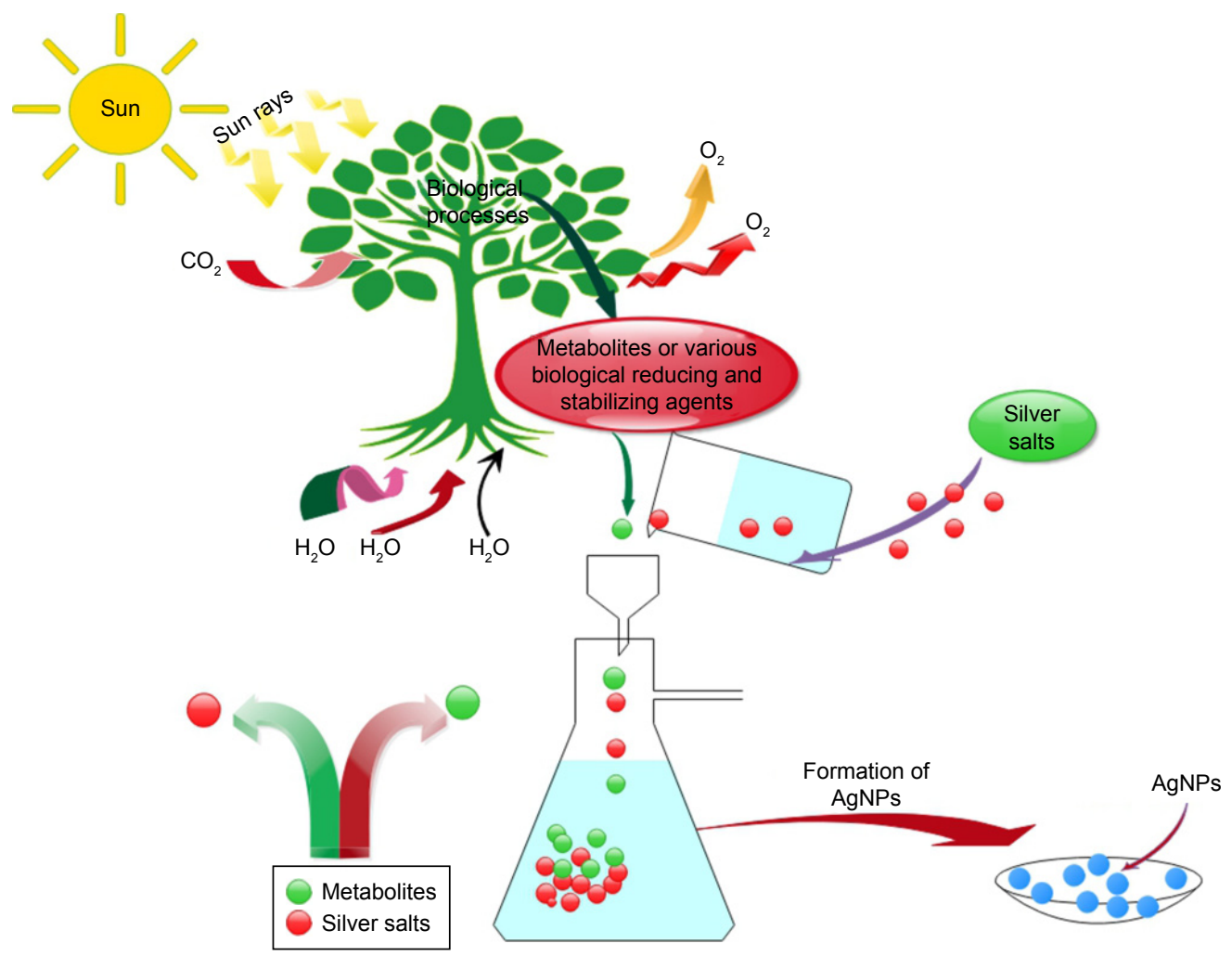

Figure 3 Biogenic or green synthesis of AgNPs. Abbreviation: AgNPs, silver nanoparticles.

AgNPs. ${ }^{126}$ Penicillium spp. were also used for the production of AgNPs. ${ }^{163}$ Soil-isolated Penicillium spp. J3 which has the ability to produce silver nanoparticles was used for the synthesis, and the AgNPs formation took place on the surface of the cells in which proteins acted as stabilizing agents. ${ }^{164}$

The spherical nanosilver can also be synthesized using Coriolus versicolor, but the reduction of AgNPs is time consuming (ie, $72 \mathrm{~h}$; however, the duration could be reduced to $1 \mathrm{~h}$ by tailoring the reaction conditions using alkaline media at $\mathrm{pH}$ 10). The alkaline media play a vital role in the bioreduction of silver ions, water hydrolysis, and interaction with protein functionalities. Furthermore, the $\mathrm{S}-\mathrm{H}$ group from the protein plays an excellent role in the bio-reduction, whereas glucose molecule also plays a significant role in the reduction of AgNPs. ${ }^{165}$ Aspergillus flavus can also be used to obtain stable nanosilver with more than 3 months of stability in aqueous solution. Meanwhile, the stabilizing agents released by fungal species ensure prevention of aggregation. ${ }^{166}$

\section{Algae}

Algae have been recently studied for the synthesis of AgNPs. Venkatpurwar and Pokharkar reported the formation of AgNPs from aquatic red algae using sulfated polysaccharides. These AgNPs were highly constant at broad
$\mathrm{pH}$ range (2-10) and showed effective antibacterial activity against Gram-negative than Gram-positive bacteria. ${ }^{167}$ El-Rafie et al extracted water-soluble polysaccharides from aquatic microalgae. These polysaccharides were used as both reducing and stabilizing agents for AgNPs formation. The colloidal solutions imparted antimicrobial activity when tested on cotton fabrics. ${ }^{168}$ More recently, Salari et al were able to synthesize AgNPs from macroalgae Spirogyra varians through bio-reduction of silver ions. These AgNPs functioned as efficient bactericidal mediators in response to many pathogenic bacteria. ${ }^{169}$ Some other algal species, namely Tetraselmis gracilis, Chaetoceros calcitrans, Isochrysis galbana, and Chlorella salina, can be successfully used for the AgNPs biosynthesis. ${ }^{170}$

\section{Polysaccharides}

Polysaccharides have been widely used for biomedical applications, as they are biocompatible and biodegradable. Polysaccharides are considered as excellent templates for the preparation of nanosilvers. Polysaccharides play a dual role, that is, reductants and/or capping agents, in the synthesis of AgNPs. For more than a decade, gentle heating of starch (capping agent) and $\beta$-D-glucose (reducing agent) has resulted in the formation of AgNPs. ${ }^{171}$ 
The starch solution (reducing/capping agent) and $\mathrm{AgNO}_{3}$ (salt) have been used for the synthesis of AgNPs, and using these agents, stable AgNPs sized 10-34 nm were formed. These nanoparticles were stable in the aqueous solution at $25^{\circ} \mathrm{C}$ for around 3 months. ${ }^{172}$ Similarly, smallsized AgNPs (5-20 and $\leq 10 \mathrm{~nm}$ ) can be prepared using starch (stabilizer and capping agent) and $\mathrm{NaOH}$ solution having glucose (reducing agent). ${ }^{173,174}$ Small-sized (1-21 nm) and spherical-shaped AgNPs have been synthesized using carboxymethyl starch in aqueous solution with a stability of more than 3 months at $25^{\circ} \mathrm{C}$. ${ }^{175}$ The alkaline solutions can also be used for solubilization of spherical nanoparticles in starch. ${ }^{176}$ Recent studies revealed that ester of alginic acid (sodium and calcium alginate) can be used for the preparation of AgNPs. ${ }^{177,178}$ Some studies also reported that the spherical-shaped and small-sized (1-4 nm) AgNPs can be obtained in $1 \mathrm{~min}$ from sodium alginate using water as solvent at $70^{\circ} \mathrm{C} .{ }^{179}$

It was also found that gum ghatti and gum kondagogu can be used as stabilizer and reducing agent for the synthesis of AgNPs. ${ }^{180,181}$ Using gum ghatti, narrow-sized (4.8-6.4 nm)
AgNPs were produced, whereas gum kondagogu produced 2-9 nm AgNPs. ${ }^{181}$ Moreover, AgNPs of undetectable size to $25 \mathrm{~nm}$ (spherical) were also obtained from alkali-soluble xanthan and acacia. ${ }^{182,183}$ Schizophyllan ${ }^{184}$ and hyaluronic acid (HA) ${ }^{185}$ were used as reducer and stabilizing agent for the synthesis of AgNPs. HA was analyzed chemically and thermally, and the results showed that 5-30 nm AgNPs can be obtained. ${ }^{185}$ Similarly, carboxymethyl chitosan and $N$-phthaloyl chitosan were also used in the preparation of nanosilver. ${ }^{186-188}$ In a recent report, it was investigated that under acidic medium, silver chitosan film was formed due to the mixing of both silver salts and chitosan. ${ }^{189}$ Also, acidic medium and chitosan were used as chelating agents for AgNPs. ${ }^{190}$

Cellulose is also one of the most important groups of polysaccharides, and due to its unique properties, cellulose is considered as an excellent template for the nanosilver formation. Both soluble and insoluble cellulose have been employed for the preparation of AgNPs, where alcohol and aldehyde groups performed an important role in the stabilization and reduction of silver ions ${ }^{191}$ as presented in Figure 4.

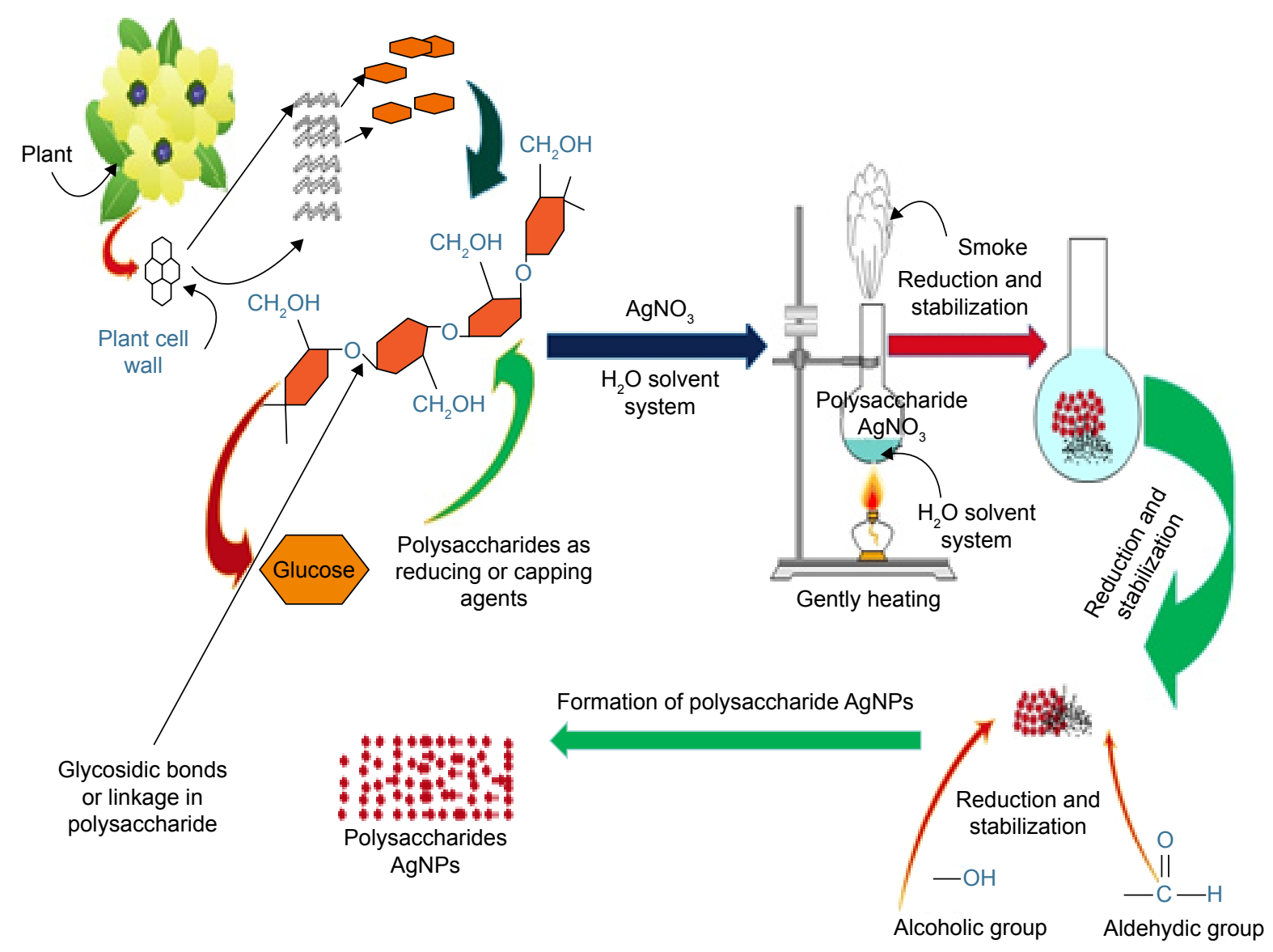

Figure 4 Polysaccharides-based synthesis of AgNPs in which polysaccharides (cellulose), alcohol, and aldehyde groups act as stabilizing agents.

Abbreviation: AgNPs, silver nanoparticles. 
Recently, the green synthesis of AgNPs using hydroxyl propyl cellulose (HPC) has also been reported. HPC plays a dual role (reducer and stabilizer) in the synthesis of AgNPs. ${ }^{192,193}$ Insoluble cellulose was also investigated for the synthesis of AgNPs. Furthermore, it was indicated that various types of fibers were used in the silver salt solution. Meanwhile, experimental results showed that AgNPs of undetectable size to 160 and $50 \mathrm{~nm}$ were deposited on cotton and viscose fibers, respectively. Recently, cotton fabrics were investigated for the synthesis of the AgNPs. Trisodium citrate was used as a reducing agent at $90^{\circ} \mathrm{C}$. Experimental results indicated that 20-90 nm AgNPs can be obtained. ${ }^{194}$

\section{Synthesis of AgNPs by proteins and DNA}

Sericin, a globular glue protein, is exclusively produced in the middle silk gland of silkworm when silkworm spins a cocoon for protective and adhesive effects. ${ }^{195}$ Silkworm cocoon is usually composed of about 75\% fibroin and 25\% sericin. However, sericin has been disposed of as a waste during the silk reeling process in the past few thousand years. It is not only a great waste of natural resources but also causes serious environmental pollution. Modern studies propounded that sericin performs a variety of biological activities, such as anticoagulation, antioxidant, antibacterial, and mitogenic effects, on mammalian cells. In regenerative medicines, it is usually mingled with functional polymers to form various scaffolds for biomedical purposes. ${ }^{195}$

Silk fibroin is a natural protein present in silkworm silk and is a common biomacromolecule with a unique sequencespecific self-assembling behavior. ${ }^{119,196}$

Over the past decade, silk fibroin has been applied in tissue engineering as a degradable surgical suture and scaffold ${ }^{197,198}$ for its good biocompatibility, controllable biodegradability, and easy fabrication into different forms, such as fibers, films, gels, and three-dimensional scaffolds. ${ }^{199}$ Silk fibroin is a good candidate for biomineralization. Previous works have indicated that silk fibroin regulates the morphologies of inorganic nanoparticles during the biomineralization process. ${ }^{200,201}$ Silk fibroin contains 18 types of amino acid residues, including some polar amino acids such as tyrosine (Tyr). Tyr endows silk fibroin with the electron-donating property. The electron-donating property of the phenolic hydroxyl group of Tyr could directly reduce silver ion to AgNP. ${ }^{202}$ Thus, it is possible to synthesize AgNPs through the reduction of $\mathrm{Ag}^{+}$by silk fibroin in situ to prepare the antibacterial silk film. Biopolymer film such as AgNPs silk is limited in its packaging application due to its poor mechanical property. To improve the mechanical property, biopolymer-polymer interaction is developed by blending natural biopolymers with polymers. PVA is a biodegradable, biocompatible, water-soluble, and nontoxic semicrystalline polymer. It offers good thermomechanical property, thermal stability, mechanical strength, and flexibility, as well as good optical and physical properties that are crucial for packaging application. ${ }^{203,204}$ Moreover, PVA is approved by the US Food and Drug Administration as an indirect food additive for flexible food packaging. ${ }^{205,206}$ The combination of AgNPs, silk fibroin, and PVA will be promising for active packaging.

Graphene oxide (GO), an oxidized form of graphene, has been extensively used for various applications since the discovery of graphene in $2004 .^{207}$ Recently, GO has been utilized as a platform for growing NPs or attaching pre-synthesized NPs on its surface to produce NP-GO nanocomposites (NCs). Interestingly, NP-GO NCs exhibit enhanced surface enhanced Raman scattering, catalytic, and antibacterial properties compared to bare GO and NP. ${ }^{208-213}$ Recent studies reported the fabrication of AgNPs-decorated GO as an effective antibacterial agent. ${ }^{213-216}$

Synthesis of AgNPs decorated on magnetic GO NCs was demonstrated, which showed highly effective inhibitory property and reusability even at the very low concentration (12.5 ppm). ${ }^{217}$

\section{Biomedical applications of AgNPs Bactericidal property of AgNPs}

Antimicrobial activities of AgNPs as presented in Figures 1 and 5 have been known for many centuries, but their assessment on a scientific basis has only been realized in recent years. Sondi and Salopek-Sondi for the first time depicted AgNPs performance against E. coli, to propose a possible enlightenment of the observed action of AgNPs on bacteria. The authors revealed that the appearance of "pits" in bacterial cell wall and accumulation of AgNPs in the cellular membrane resulted in an enhanced permeability of cell wall and eventually induced bactericidal activity. ${ }^{218}$

Devi and Joshi evaluated 53 strains of various fungi for the mycosynthesis of AgNPs and showed considerable effectiveness of AgNPs against Streptococcus pyogenes, Salmonella enterica, S. aureus, and Enterococcus faecalis. ${ }^{219}$ Moreover, the mycosynthesized nanoparticles also exhibited potential antibacterial activity and synergistic effect with erythromycin, chloramphenicol, methicillin, and ciprofloxacin against Enterobacter aerogenes and K. pneumoniae ${ }^{66}$ and with antibiotics ampicillin, tetracycline, gentamycin, and streptomycin against E. coli, S. aureus, and Pseudomonas aeruginosa. ${ }^{220}$ The antibacterial activity of AgNPs strongly 
depends on the size of the silver particles as reported in previous reports. AgNPs with a smaller size have high activity due to a relative increase in contact surface. ${ }^{221}$

Shameli et al reported size-based bactericidal potential of various AgNPs prepared in PEG against $S$. aureus and Salmonella typhimurium bacteria using disc diffusion method. AgNPs were found to be very effective and cause momentous inhibition of both strains. They summarized that the bactericidal potential of AgNPs in PEG can be tuned by controlling the size of nanoparticles, since smaller particles have a relatively greater contact surface area than larger particles. The factors that are influencing the activity of AgNPs (size, shape, concentration, UV radiation, and combination with different antibiotics) should be taken into account during the preparation processes and medicinal applications of AgNPs. ${ }^{222}$ Similarly, investigations by Raheman et al and Gade et al had already demonstrated the biocidal potential of AgNPs, respectively. ${ }^{67,223}$ Silver bionanocomposite films having a size less than $20 \mathrm{~nm}$ were tested against E. coli, P. aeruginosa, S. aureus, and Micrococcus luteus. These silver composites exhibited satisfactory antibacterial properties. ${ }^{224}$

In recent studies, spherical-shaped 20,18, and $15 \mathrm{~nm}$ AgNPs were prepared. The experimental result showed that all AgNPs were active against different strains of bacteria. ${ }^{13,17}$ In another study, AgNPs having a spherical shape and ranging in size from 5 to $30 \mathrm{~nm}$ and crude latex aqueous extract were tested against different bacterial pathogens such as Enterococci spp., B. cereus, Shigella spp., P. aeruginosa, $S$. aureus, K. pneumoniae, and E. coli. These biosynthesized AgNPs were found to have the capability of enhancing the antimicrobial activity compared to crude latex aqueous extract. $^{225}$ The nanoparticles assumed spherical geometry and were often aggregated into small particles with quite a uniform size of 12.50-41.90 nm. These AgNPs showed exceptional antibacterial property against different strains of bacteria. Afterwards, they were found to be more effective against $E$. coli and $K$. pneumoniae than against $E$. faecalis and $S$. mutans. This differential activity may possibly be due to the difference in bacterial cell wall structure. ${ }^{226}$

Recently, AgNPs with an average uniform size of $5 \mathrm{~nm}$ were tested against bacteria. Results indicated that the efficiency of antibiotics was improved in the presence of AgNPs against test strains. The activity of AgNPs was more pronounced with ampicillin against the Gram-negative bacteria Shigella flexneri and $P$. aeruginosa, and vancomycin against the Gram-positive bacteria Streptococcus pneumoniae and $S$. aureus. More interestingly, these antibiotics exhibited higher antimicrobial efficiency in association with AgNPs.
These results suggested that AgNPs could be used as an adjuvant for curing various infectious diseases caused by bacteria. ${ }^{4}$ AgNPs which were synthesized by the green method and their antibacterial properties were studied using diffusion method. The concentration of AgNPs was varied as $25,50,75$, and $100 \mu \mathrm{g} / \mathrm{mL}$. The highest efficiency of AgNPs was found against $S$. aureus $(23 \mathrm{~mm})$ and $E$. coli $(28 \mathrm{~mm})$. The moderate activity was obtained against Salmonella typhi $(18 \mathrm{~mm})$ followed by M. luteus $(15 \mathrm{~mm})$ and $P$. aeruginosa $(13 \mathrm{~mm}) .{ }^{19}$

AgNPs, having a size of $26 \mathrm{~nm}$, have been reported to be efficient against $E$. faecalis CCM 4224, $S$. aureus CCM 3953, E. coli CCM 3954, and P. aeruginosa CCM 3955. The modified antibacterial activity of silver NPs was considerably improved as confirmed by minimum inhibitory concentration (MIC) values ranging from 6.75 down to $0.84 \mu \mathrm{g} / \mathrm{mL} .^{227}$ In another study, the growth rates of bacteria were studied under varying AgNPs concentrations, incubation temperatures, times, and pH. E. coli and S. aureus were shown to be substantially inhibited by AgNPs, and the antibacterial activity of AgNPs did not change with $\mathrm{pH}$ or temperature. $^{228}$

AgNPs in montmorillonite were prepared, and their antibacterial activities against $S$. aureus and methicillin-resistant S. aureus (Gram-positive bacteria) and E. coli, E. coli O157:H7, and $K$. pneumoniae (Gram-negative bacteria) were tested by the disc diffusion method using MuellerHinton agar. The smaller AgNPs exhibited significantly higher antibacterial activity. ${ }^{229}$ More recently, cream formulations of AgNPs and $\mathrm{AgNO}_{3}$ were prepared, and their antibacterial activity was evaluated on human pathogens (S. aureus, Proteus vulgaris, E. coli, P. aeruginosa, and Candida albicans) and a plant pathogen (Agrobacterium tumefaciens). The antimicrobial studies concluded that AgNPs have 200 times more inhibitory effect compared to $\mathrm{AgNO}_{3}$. The AgNPs act by damaging the cell membrane of E. coli, which was confirmed by SEM study. ${ }^{230}$

The antibacterial activity of AgNPs was tested against nine human diseases-causing Gram-negative bacteria and one Gram-positive bacteria. AgNPs extracts had the capability to enhance antibacterial activity against all tested strains compared to the extracts alone. AgNPs were more bactericidal in liquid than in solid medium, probably due to better contact with bacterial cells in a liquid state. Maximum zone of inhibition was $19 \mathrm{~mm}$ for nanoparticles of leaves on P. aeruginosa (ATCC278223) and $18 \mathrm{~mm}$ for latex nanoparticles on S. flexneri (ATCC12022). The minimum zone of inhibition was $7 \mathrm{~mm}$ for both nanoparticles of leaves 
and latex on S. typhi (ATCC19430) and S. typhimurium (ATCC14028), respectively. ${ }^{231}$

The leaf extract of Lantana camara was used for the biosynthesis of AgNPs. These nanoparticles were evaluated for catalytic and antibacterial activities. The biosynthesized nanosilver had excellent potential against the tested strains including E. coli, Pseudomonas spp., Bacillus spp., and Staphylococcus spp. Moreover, these AgNPs also showed higher catalytic activity in the reduction of methylene blue observed using UV-vis spectrophotometer. ${ }^{232}$ Spherical nanosilver sized 10-15 nm was synthesized from fresh spinach leaves. These nanoparticles had strong bactericidal potential and good catalytic property toward methyl red and methylene blue. ${ }^{233}$

A recent study on the effect of AgNPs (13.4 nm) against $E$. coli and $S$. aureus found their MIC values to be below $6.6 \mathrm{nM}$ and above $33 \mathrm{nM}$, respectively. ${ }^{234}$ Another study was conducted against the bacterium E. coli. The results showed that AgNPs (16 nm) had the ability to inhibit E. coli colony-forming unit at a concentration of $60 \mu \mathrm{g} / \mathrm{mL} .{ }^{235}$ Furthermore, the activity of some important dendrimer (polyamidoamine) Ag-composites has also been reported against E. coli, S. aureus, P. aeruginosa, Klebsiella mobilis, and Bacillus subtilis. ${ }^{104}$

The antimicrobial property of AgNPs is most exploited in the medical field, though their anti-inflammatory nature is also considered immensely useful. Initial studies have suggested that the acceleration of wound healing in the presence of nanoparticles is due to the reduction of local matrix metalloproteinase activity and the increase in neutrophil apoptosis within the wound.

Recent evidence suggests that nanosilver has a potent anti-inflammatory effect ${ }^{236-238}$ and accelerates wound healing. ${ }^{239,240}$ Silver has long been known to possess antibacterial activity and has been used throughout history, from Hippocrates' early treatment of ulcers to C.S.F. Crede's treatment of gonococcal infections in newborns. Silver is still used clinically, and nanosilver is emerging as a valuable tool in the therapeutic armory (Figure 5). Silver sulfadiazine is the gold standard for the topical treatment of burn patients. ${ }^{241}$ The resurgent interest in silver and nanosilver has been motivated by the emergence of rampant antibiotic-resistant bacteria and the increasing prevalence of hospital-acquired bacterial infections. The use of silver has been severely limited by the toxicity of silver ions to humans; however, nanotechnology has facilitated the production of smaller silver particles with increasingly large surface area-to-volume ratios, greater efficacy against bacteria, ${ }^{242,243}$ and most importantly, lower toxicity to humans. ${ }^{244}$

Nanocrystalline silver wound dressings have been commercially available for over a decade (eg, Acticoat ${ }^{\mathrm{TM}}$ ) and are in current clinical use for the treatment of various wounds, including burns, ${ }^{240,245,246}$ toxic epidermal necrolysis, ${ }^{247}$ StevensJohnson syndrome, ${ }^{248}$ chronic ulcers, ${ }^{237}$ and pemphigus. ${ }^{248}$

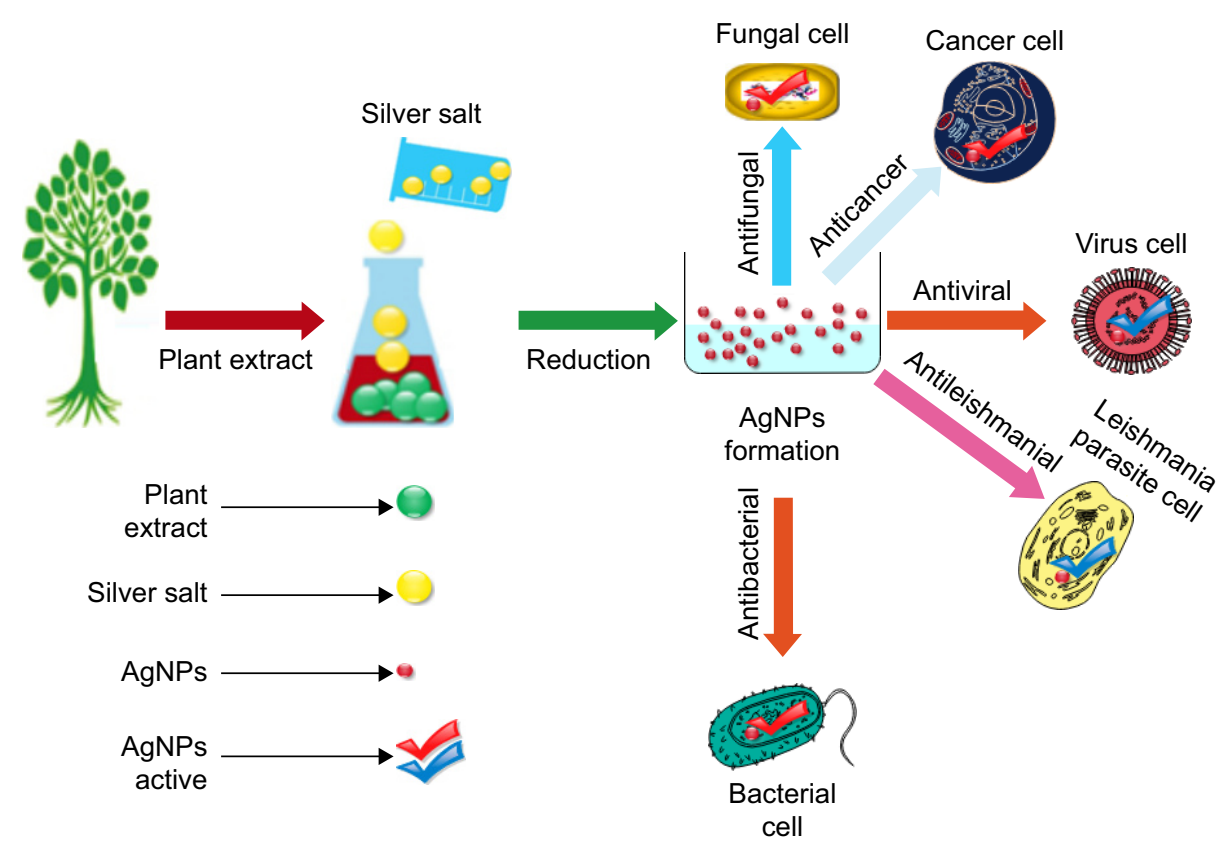

Figure 5 Graphical abstract representing the synthesis (green) and the biocidal potential of AgNPs against various microbes. Abbreviation: AgNPs, silver nanoparticles. 
Typical dressings consist of two layers of polyethylene mesh forming a sandwich around a layer of polyester gauze. Typical nanocrystalline coatings are $900 \mathrm{~nm}$ thick with a crystallite size of $10-15 \mathrm{~nm}^{236}$ and are applied to the polyethylene layer.

\section{Antifungal property of $\mathrm{AgNPs}$}

In 2008, Kim et al demonstrated the potential of AgNPs against 44 strains of six fungal species, namely Candida tropicalis, C. albicans, Candida glabrata, Candida krusei, Candida parapsilosis, and Trichophyton mentagrophytes. The AgNPs were found active against various strains of T. mentagrophytes and Candida spp. ${ }^{249}$ Similarly, Velluti et al found that nanosilver complexes $\left[\mathrm{Ag}_{2}(\mathrm{SMX})_{2}\right]$ showed good activity against 10 fungal strains, namely C. tropicalis (C 131), C. albicans (ATCC 10231), Cryptococcus neoformans (ATCC 32264), Saccharomyces cerevisiae (ATCC 9763), A. fumigatus (ATCC 26934), A. flavus (ATCC 9170), Aspergillus niger (ATCC 9029), dermatophytes including Trichophyton rubrum (C 113), T. mentagrophytes (ATCC 9972), and Microsporum gypseum (C 115). ${ }^{250}$

Gajbhiye et al reported the efficiency of biogenic AgNPs against Pleospora herbarum, Phoma glomerata, Fusarium semitectum, Trichoderma spp., and C. albicans. Furthermore, they also reported the synergistic effects of AgNPs in association with fluconazole. ${ }^{251}$ In 2009, Jo et al demonstrated the antifungal potential of silver ions and nanoparticles against two plant pathogenic fungi, Magnaporthe grisea and Bipolaris sorokiniana. The fungicidal potential of AgNPs in combination with various heterocyclic compounds like phthalazine, thiazolidine, hydrazide, pyrazolo, tetrazolo, and pyridazine derivatives was studied against $C$. albicans and A. flavus, and the AgNPs were found to have significant fungicidal activity against tested organisms. ${ }^{252}$

Recently, six fungal species, namely Penicillium brevicompactum, A. fumigatus, Mortierella alpina, C. cladosporoides, Chaetomium globosum, and Stachybotrys chartarum, were selected for the study of the antifungal activity of AgNPs. The growth rates of all tested fungal species, except Mortierella spp., were affected by the addition of AgNPs, which caused the limitation of Chaetomium and Stachybotrys on gypsum products. Each fungus showed a distinct response to applied AgNPs depending upon the concentration and the rate of $\mathrm{Ag}$ ions released into the environment. ${ }^{253}$

In 2010, Jaidev and Narasimha demonstrated the antifungal (A. niger) and antibacterial (Staphylococcus spp., E. coli, Bacillus spp.) activities of AgNPs. They reported that nanosilver has excellent inhibitory activity against $A$. niger confirming the maximum activity as compared to Bacillus spp. $(0.8 \mathrm{~cm})$, Staphylococcus spp. $(0.9 \mathrm{~cm})$, and E. coli $(0.8 \mathrm{~cm}) .{ }^{69}$ Meanwhile, Nasrollahi et al studied the fungicidal potential of AgNPs against $S$. cerevisiae and C. albicans. Their results were productive confirming the excellent potential of AgNPs as compared to standard antifungal agents (viz. fluconazole and amphotericin B). ${ }^{254}$ Savithramma et al prepared AgNPs using a different extract of medicinal plants, Shorea tumbuggaia, Boswellia ovalifoliolata, and Svensonia hyderobadensis, to evaluate their antifungal activity against A. niger, Curvularia spp., A. flavus, Fusarium spp., and Rhizopus spp. The results confirmed that all biogenic AgNPs showed considerable antifungal activity against various fungal spp. The AgNPs synthesized with $S$. hyderobadensis exhibited higher activity as compared to AgNPs synthesized using the other two plants. ${ }^{255}$

Kaur et al reported the fungicidal potential of silver and chitosan nanoparticles against A. flavus, Rhizoctonia solani, and Alternaria alternata from chickpea seeds. ${ }^{256}$ In 2012, Arjun and Bholay also demonstrated the momentous efficiency of AgNPs against T. rubrum, C. albicans, and $A$. fumigatus. ${ }^{257} \mathrm{Xu}$ et al also tested nanosilver and natamycin against 216 strains of fungi from patients suffering from severe keratitis. These included 82 isolates of Aspergillus, 112 isolates of Fusarium, and 10 isolates of Alternaria. Results demonstrated that AgNPs had higher activity as compared to natamycin. ${ }^{258}$ Similarly, Dar et al studied the biocidal potential of AgNPs synthesized from Cryphonectria spp. against S. typhi, E. coli, S. aureus, and C. albicans, concluding that AgNPs can be used as potential antifungal agents. ${ }^{64}$

More recently, the antifungal activity of mycosynthesized AgNPs was tested for the first time against plant pathogenic fungi. AgNPs displayed good antifungal activity against Colletotrichum spp. (12.63 $\mathrm{mm})$ followed by $R$. solani $(12.03 \mathrm{~mm})$ and Cochliobolus lunata $(11.23 \mathrm{~mm})$ at $1 \mathrm{mg} / \mathrm{mL}$ concentration. The nanoparticles were less effective against Fusarium spp. $(9.37 \mathrm{~mm}) .{ }^{259} \mathrm{In}$ another study, $\mathrm{AgNO}_{3}$ was tested against three fungi namely Trichoderma spp. (ATCC 18648), Mucor spp. (ATCC 48559), and A. niger (ATCC 6275), and it was found to exhibit good antifungal activity. ${ }^{260}$

The antifungal activity of AgNPs against $C$. tropicalis and $C$. albicans was also investigated. Stable nanoparticles of size $12.5 \pm 4.9 \mathrm{~nm}$ (mean $\pm \mathrm{SD}$ ) were obtained, which presented high activity against Candida spp. ${ }^{261}$ The spherical and polydispersed AgNPs, ranging in size from 4 to $36 \mathrm{~nm}$ and 8 to $60 \mathrm{~nm}$, respectively, were applied against superficial mycoses caused by T. rubrum, Malassezia furfur, C. albicans, 
and $C$. tropicalis. The AgNPs exhibited highest antifungal activity against $T$. rubrum and the least against $M$. furfur and C. albicans as compared to others. ${ }^{262}$

C. glabrata and C. krusei were exposed to spherical nanoparticles $(19 \mathrm{~nm})$ with positive surface charge. The MIC50 values were $0.1-1 \mathrm{~g} \mathrm{~mL}^{-1} \mathrm{AgNPs}$, and minimum fungicidal concentration (MFC) values were 0.25 and $0.5 \mathrm{~g} \mathrm{~mL}^{-1}$ for C. glabrata and C. krusei, respectively. ${ }^{263}$ Meanwhile, another research confirmed that concentrations of AgNPs between 10 and $25 \mu \mathrm{M}$ reduced the growth rates of the tested fungus and bacteria and showed the bactericidal/fungicidal activity by delaying the exponential and stationary phases. However, complete inhibition of the growth of C. albicans MTCC183 was found at a concentration of $10 \mu \mathrm{M}$ AgNPs. ${ }^{264}$

A more recent report showed that AgNPs (spherical, 1-40 $\mathrm{nm}$ ) had excellent antifungal activity against $R$. solani cultures by inhibiting $83 \%$ of the mycelium growth at $25 \mu \mathrm{g} / \mathrm{mL}$ concentration. ${ }^{265}$ In another study, several essential oils were tested for their antifungal activity. The oil isolated from the bark of Cinnamomum cassia had the highest activity against MIC and MFC values for all tested strains in the range of $0.0006 \%-0.0097 \%(\mathrm{v} / \mathrm{v})$ and $0.0012 \%-0.019 \%(\mathrm{v} / \mathrm{v})$, respectively.

Further studies were carried out about the antifungal activity of AgNPs against some Candida spp. The fungicidal efficacy of AgNPs functionalized with PVP was established. The PVP-functionalized silver particles demonstrated no damage to fungi until the exposure time was $24 \mathrm{~h}$. After $24 \mathrm{~h}$, no viability of fungal cells was observed. The work revealed that Ag particles aggregate outside the fungal cells, releasing free silver ions and thus inducing cell necrosis through the reduction process. ${ }^{266} \mathrm{Naz}$ et al synthesized silver particles capped with 5-amino- $\beta$-resocyclic acid hydrochloride dehydrate (AR). They analyzed their nanostructures before and after conjugation to silver metal for in vitro antifungal, antibacterial, antioxidant, and enzyme inhibitory properties. The results indicated that the fungicidal activity of Ag, AR, and Ag AR were not momentous as compared to the dithaneM45 (standard fungicide). ${ }^{267}$

\section{Anticancer property of AgNPs}

AgNPs have been popular for their antibacterial and antifungal activities. However, recent studies have exploited $\mathrm{AgNO}_{3}$ potential in neoplastic maladies. Recently, ecofriendly AgNPs were synthesized from the leaf extracts of Vitex negundo ${ }^{268}$ and Sesbania grandiflora, and their efficacy was tested against human colon cancer cell lines HCT15 and MCF-7, respectively. The results demonstrated that AgNPs obtained from $V$. negundo showed antiproliferative effects on cancer cell line, reduced DNA synthesis, and induced apoptosis. ${ }^{268}$ Similarly, nanosilver obtained from $S$. grandiflora also caused cytotoxicity, oxidative stress, and apoptosis in tumor cells. ${ }^{269}$ Moreover, green-synthesized AgNPs from the leaves extract of Podophyllum hexandrum and Suaefa monoica were examined and found to show cytotoxic activity and apoptotic effect, respectively. ${ }^{270,271}$

Piao et al demonstrated that $\mathrm{OH}$ radicals released by the AgNPs attacked cellular molecules including DNA, proteins, and lipids to induce oxidative damages. ${ }^{272}$ In another report, it was shown that AgNPs exhibited toxicity due to some factors such as dose, size of particles, and time. In the case of MCF-7 cell culture, the toxicity was due to the dose of AgNPs. AgNPs also caused cellular damage in Human Epidermoid Larynx (Hep-2) cell line through reactive oxygen species (ROS) formation. ${ }^{273}$ Lima et al greenly synthesized nanosilver and evaluated its genotoxicity and cytotoxicity. ${ }^{63}$ Also, Durán et al studied the potential of biosynthesized AgNPs. These nanosilver particles interacted with DNA, proteins, and cellular organelles via ROS, and induced necrosis and apoptosis in the tumor cells. ${ }^{274}$

New nanocrystalline silver with a structural size of $8 \mathrm{~nm}$ customized with TAT cell penetrating peptide (AgNP-TAT) exhibited higher antitumor property in both nonresistant and MDR cells without any discrimination. The AgNP-TAT displayed outstanding efficacy in killing tumor cells, that is, up to 24-fold higher than pristine $\mathrm{AgNO}_{3}$ without TAT alteration. Moreover, the AgNP-TAT also displayed considerable reduction in adverse toxic effects, in vivo. ${ }^{275}$

Dimocarpus longan Lour. peel aqueous extract (acts as reducing and stabilizing agent) was evaluated for the synthesis and anticancer and antibacterial effects of AgNPs. The antibacterial activities of AgNPs were evaluated using dilution method, whereas their efficacy against human prostate cancer (PC-3) cells was in vitro evaluated via blue assay and Western blot by the expression of phosphorylated stat 3 , caspase-3, bcl-2, and survivin. These nanoparticles had the face-centered cubic structure (size 9-32 nm) and exhibited great bactericidal potential against both Gram-positive and Gram-negative strains of bacteria. ${ }^{276}$

In another study, Malus domestica and Origanim vulgare extracts were used for the synthesis of nanosilver. The $M$. domestica extract-biosynthesized silver had considerable effects on MCF-7 breast cancer cells, whereas silver synthesized from $O$. vulgare aqueous extracts showed dose-dependent response against human lung cancer A549 cell line. ${ }^{277,278}$ 
In a recent study, AgNPs were obtained from the stem bark extract of Moringa olifera. These biosynthesized AgNPs were tested for anticancer properties. The flow cytometry results showed apoptosis induced through ROS generation in HeLa cells. ${ }^{279}$ The rhamnolipids were isolated from $P$. aeruginosa strain JS-11 and used for the biosynthesis of Rh-AgNPs. These nanosilver particles were tested against MCF-7 human cells. ${ }^{280}$ Furthermore, caffeic acid-mediated spherical nanosilver particles of $6.67 \pm 0.35 \mathrm{~nm}$ size were used against cancer cells. The results showed that AgNPs efficiently inhibited the growth of HepG2 cells via apoptosis induction. ${ }^{281}$

Recently, spherical-shaped $(6.2 \pm 0.2 \mathrm{~nm})$ silver-(proteinlipid) nanoparticles (Ag-LP-NPs) were obtained using the seed extract of Sterculia foetida. These eco-friendly Ag-LP-NPs showed antiproliferative activity against HeLa cancer cell lines and also showed potential toxicity in a dose-dependent manner. ${ }^{282}$ More recently, biogenic AgNPs were obtained from the flower extract of Plumeria alba (frangipani) known as frangipani AgNPs (FS NPs). These FS NPs had a cytotoxic effect on COLO 205 which was determined by MTT assay, and after 24 and $48 \mathrm{~h}$ of incubation, the $\mathrm{IC}_{50}$ concentration was found at 4 and $5.5 \mu \mathrm{g} / \mathrm{mL}$, respectively. Furthermore, the FS NPs cytotoxic affect on COLO 205 cells was associated with the loss of membrane integrity and chromatin condensation that have a great role in the induction of apoptosis as evidenced by acridine orange/ ethidium bromide staining. ${ }^{283}$

On the other hand, it was also demonstrated that $\mathrm{AgNO}_{3}$ and metal-based nanoparticles (AgNPs) had strong potential for cytotoxic, antiproliferative, and apoptotic property in H-ras 5RP7 cells and cervical cancer, respectively. ${ }^{284,285}$

Biosynthesized nanosilver from the extract of Pterocladiella capillacea $(11.4 \pm 3.52 \mathrm{~nm})$ and $P$. aeruginosa $(13-76 \mathrm{~nm})$ showed great potential against human hepatocellular carcinoma (HepG2) cell lines and human cervical cancer cells (HeLa), respectively. ${ }^{286,287}$ In another study, it was found that green-synthesized nanosilver $(45 \pm 0.15 \mathrm{~nm})$ from novel Nocardiopsis spp. had potent activity against in vitro human cervical cancer cell line. $\mathrm{The}^{\mathrm{IC}_{50}}$ value was recorded in the range of $200 \mu \mathrm{g} / \mathrm{mL}$ of AgNPs against HeLa cancer cells. ${ }^{288}$ It was also found that the plumbagin-caged nanosilver induced $\sim 80 \%$ cell death at a concentration of $2.5 \mu \mathrm{M}$, whereas no cytotoxicity was observed for normal cells. ${ }^{289}$

A study published by Yeasmin et al demonstrated that AgNPs with controlled shape are more effective against many types of cancer cell lines. They stabilized the shape of spherical silver nanoparticles by interaction with natural gum and then screened against cervical cancer cell lines (HeLa), lung cancer (A549), and mice macrophage or RAW 264.7 and found that the particles effectively killed these cell lines in a dose-dependent manner. ${ }^{290}$ Venil et al reported flexirubin (a bacterial pigment)-mediated silver nanoparticles for the first time that were highly cytotoxic $\left(\mathrm{IC}_{50}\right.$ value of $36 \mu \mathrm{g} / \mathrm{mL}$ ) against human breast cancer cell lines (MCF-7). ${ }^{291}$

Nowadays, chitosan-based biosynthesized silver nanoparticles are mostly synthesized and used against different cancer cell lines. A study performed by Venkatesan et al demonstrated that porous chitosan-alginate-biosynthesized AgNPs exhibited cytotoxic effects against breast cancer cell line MDA-MB-231 $\left(\mathrm{IC}_{50}=4.6 \mathrm{mg}\right){ }^{292} \mathrm{~A}$ recent study demonstrated that loaded quinazolinone polypyrrole/chitosan silver chloride NC had active anticancer efficacy against Ehrlich ascites carcinoma cells. ${ }^{293}$ The chitosan-silver hybrid nanoparticles were proven to induce apoptosis in HepG2 cells by downregulating BCL2 gene and upregulating P53. ${ }^{294}$

\section{Antiviral property of AgNPs}

AgNPs have received enormous attention for their bactericidal potential, while the antiviral activities of metal nanoparticles remain an emergent area. The potential of AgNPs was studied in both prokaryotic and eukaryotic organisms, ${ }^{295}$ and it was reported that small-sized AgNPs of around $25 \mathrm{~nm}$ or less had outstanding potential in viral infection inhibition. ${ }^{296}$ The aqueous extract of Ricinus communis was used for the synthesis of nanoparticles, which resulted in AgNPs sized 1,000 nm. Smaller-sized (5-20 nm) AgNPs were obtained from fungi. The results indicated that the small-sized AgNPs had an excellent ability to decrease the infection potential of herpes simplex virus types (HSV) $1 / 2$ and human parainfluenza virus type $3 .^{297}$

Baram-Pinto et al investigated the inhibitory effect of AgNPs against HSV-1 and demonstrated that sulfonatecapped nanosilver inhibited HSV-1 infection. Furthermore, they demonstrated that AgNPs prevented the attachment and entry of virus into a cell or prevented the cell from spreading the virus. The heparan sulfate is a cellular primary acceptor of HSV, and thus competes with the virus for attaching to the cell and the potential was enhanced due to the presence of the inner core AgNPs. ${ }^{298}$ This study also demonstrated the virucidal action of AgNPs. These nanoparticles exhibited anti-HIV activity at an early stage of viral infection and also prevented the further replication of HIV- $1 .{ }^{299}$ Furthermore, the viruses and other microbial strains were grown under multicycler growth condition in the absence or presence of colloidal 
silver to check the antimicrobial property. As expected, no viral growth was seen with any strains tested. ${ }^{300}$

A recent study also showed that $T$ lymphocyte $(\mathrm{T})$ tropic and macrophage (M)-tropic strains of HIV-1 were extremely susceptible to the AgNPs coated with polyurethane condom. ${ }^{15}$

In a recent study, different types of nanosilver particles were biosynthesized from $F$. oxysporum $(4-13 \mathrm{~nm})$, Curvularia spp. (5-23 nm), and Alternaria and Phoma spp. (7-20 nm). Silver particles produced from $F$. oxysporum and Curvularia spp. had exceptional antiviral activity but were less cytotoxic to Vero cells, whereas particles produced from Alternaria and Phoma spp. showed moderate virucidal action. This study also confirmed that small-sized nanoparticles have excellent ability to inhibit the replication of virus as compared to larger ones. ${ }^{297}$

More recently, the tannic acid-modified AgNPs in the range of 13,33 , and $46 \mathrm{~nm}$ were found to reduce HSV-2 infectivity in vivo and in vitro. In particular, tannic acid in the same amount also showed somewhat in vivo potential against the virus. Therefore, tannic acid-modified nanosilver was used as an antimicrobial agent in addition to cream or protective gel used for oral herpes infections treatment. ${ }^{301}$

\section{Antiprotozoal property of AgNPs}

According to the WHO, leishmaniasis is the sixth most infectious disease. ${ }^{302}$ Leishmaniasis is one of the most abandoned tropical infections around the globe, with occurrence in 88 countries and a predictable number of 500,000 cases of visceral form and 1.5 million cases of cutaneous leishmaniasis. ${ }^{303}$ Rossi-Bergmann et al demonstrated the potential function of biosynthesized AgNPs (using $F$. oxysporum) against Leishmania amazonensis promastigotes both in vivo and in vitro. They also compared the biologically and chemically synthesized AgNPs. Their results demonstrated that biosynthesized nanosilver was four times more active as compared to chemically produced AgNPs in vitro, while the in vivo results showed it was even more effective. ${ }^{304}$

The protozoal vector-borne diseases are the most common and important infections in developed regions, resulting in over one million deaths from malaria on yearly bases, worldwide. $^{305}$ To control the malaria vector, researchers strive to discover innovative approach against antimalarial agents. Among various antimalarial drugs, AgNPs have also been evaluated against malarial parasites and reported with promising potential against malaria. In recent studies, the biologically synthesized AgNPs from Andrographis paniculata Nees. (Acanthaceae) $\sim 55 \mathrm{~nm}$ in size ${ }^{306}$ and Catharanthus roseus leaves (approximate size $35-55 \mathrm{~nm}$ ) were tested against $P$. falciparum. ${ }^{307}$ In another study, the higher antimalarial potential of AgNPs was reported. The AgNPs were bio-reduced in 5\% Cassia occidentalis leaf broth against chloroquine-sensitive and chloroquine-resistant strains of P. falciparum and malarial vector Anopheles stephensi. ${ }^{232}$

\section{Mechanism of action of AgNPs in biological systems}

To date, there is no proper mechanism for the synthesis of AgNPs. A proposed hypothetical mechanism behind the synthesis of nanoparticles is an enzymatic reaction in which the complex of reducing enzymes present in the plant, fungal, or bacterial extract reduces the chemicals such as $\mathrm{AgNO}_{3}$ into silver ions and nitrate ions. ${ }^{308}$

Plants contain a complex network of antioxidant metabolites and enzymes that work together to prevent oxidative damage to cellular components. It was reported that plant extracts contain biomolecules including polyphenols, ascorbic acid, flavonoids, sterols, triterpenes, alkaloids, alcoholic compounds, polysaccharides, saponins, $\beta$-phenylethylamines, glucose and fructose, and proteins/enzymes which could be used as reductants to react with silver ions and therefore used as scaffolds to direct the formation of AgNPs in the solution. Hypothetically, biosynthetic products or reduced cofactors play an important role in the reduction of respective salts to nanoparticles. However, it seems probable that some glucose and ascorbate reduce $\mathrm{AgNO}_{3}$ and $\mathrm{HAuCl}_{4}$ to form nanoparticles. ${ }^{131,140,308,309}$ In neem leaf broth, terpenoids are the surface-active molecules stabilizing the nanoparticles, and reaction of the metal ions is possibly facilitated by reducing sugars. ${ }^{310}$ A study using Capsicum annuum extract also indicated that the proteins which have amine groups played a reducing and controlling role during the formation of AgNPs in the solutions and that the secondary structure of the proteins changed after reaction with silver ions. ${ }^{141}$ Ficus benghalensis leaf contains antioxidants and polyphenols (flavonoids), and it can also directly scavenge molecular species of active oxygen. Antioxidant action of flavonoids resides mainly in their ability to donate electrons or hydrogen atoms, that is, change keto group to enol form. Proteins, enzymes, phenolics, and other chemicals within plant leaf extract reduce silver salts and also provide excellent tenacity against agglomeration, which can be further studied to understand the mechanism of evolution by biological systems. ${ }^{309,311}$

The precise and accurate mechanism of action of AgNPs is still far from being understood completely. However based 
on previously reported studies, we summarize the AgNPs mechanism in different biological systems such as bacteria, human, fungi, virus, leishmania, and protozoa.

Figure 6 shows the mechanism of action of AgNPs in a biological system. The antiviral mechanism of AgNPs, as depicted in Figure 6A, begins after the attachment of the virus to host cell during which the virus inserts its genetic material into the cell. Silver particles bind to the genetic material and block its replication which ultimately leads to translational inhibition, and in this way, viral growth is inhibited. Wound healing and antibacterial mechanism of AgNPs are shown in Figure 6B. Although not reported in the literature, we assume that AgNPs may react with free oxygen in the wound portion followed by its ionization. This ionized active silver may regulate $\mathrm{FOXO1}$ which is a transcription factor stimulating wound healing molecule, TGF- $\beta 1$. Furthermore, active silver has also been reported to generate ROS. In the eukaryotic system, the ROS activate JNK and p53 proteins which induce Bax proteins to migrate to the mitochondrial surface resulting in cytochrome $\mathrm{C}$ release from mitochondria which subsequently results in PARP cleavage. This phenomenon leads to apoptosis. The antibacterial mechanism of AgNPs starts with adhesion of AgNPs to bacterial cell followed by pit formation through which AgNPs enter the cell. These AgNPs then bind to nuclear material residing inside the bacteria. This leads to transcriptional and translational disruption and subsequently leads to ROS generation, which results in antibacterial activity.

\section{Antibacterial activity}

As reported for other metals, it is assumed that AgNPs may undergo redox reaction leading to the generation of free radicals (ROS, reactive nitrogen species) which triggers cytotoxicity in bacterial cells. The AgNPs first adhere to the bacterial cell wall leading to destabilization of cell membrane potential and low levels of ATPs in the cell followed by cell death. ${ }^{312,313}$ There are some assumptions regarding AgNPsinduced bacterial cell death.

First, silver ions produced from AgNPs inside bacterial cells may interact with cellular glutathione and oxidize it. This phenomenon leads to the generation of ROS which consequently triggers bacterial growth inhibition. ${ }^{314}$ Second, the oxidized glutathione may result in an increased lipid peroxidation leading to membrane disruption, thereby resulting in leakage of cellular constituents. ${ }^{272}$ Third, DNA contains sulfur and phosphorous groups. AgNPs may bind to these groups leading to unwinding of DNA which may lead to transcriptional and translational

A

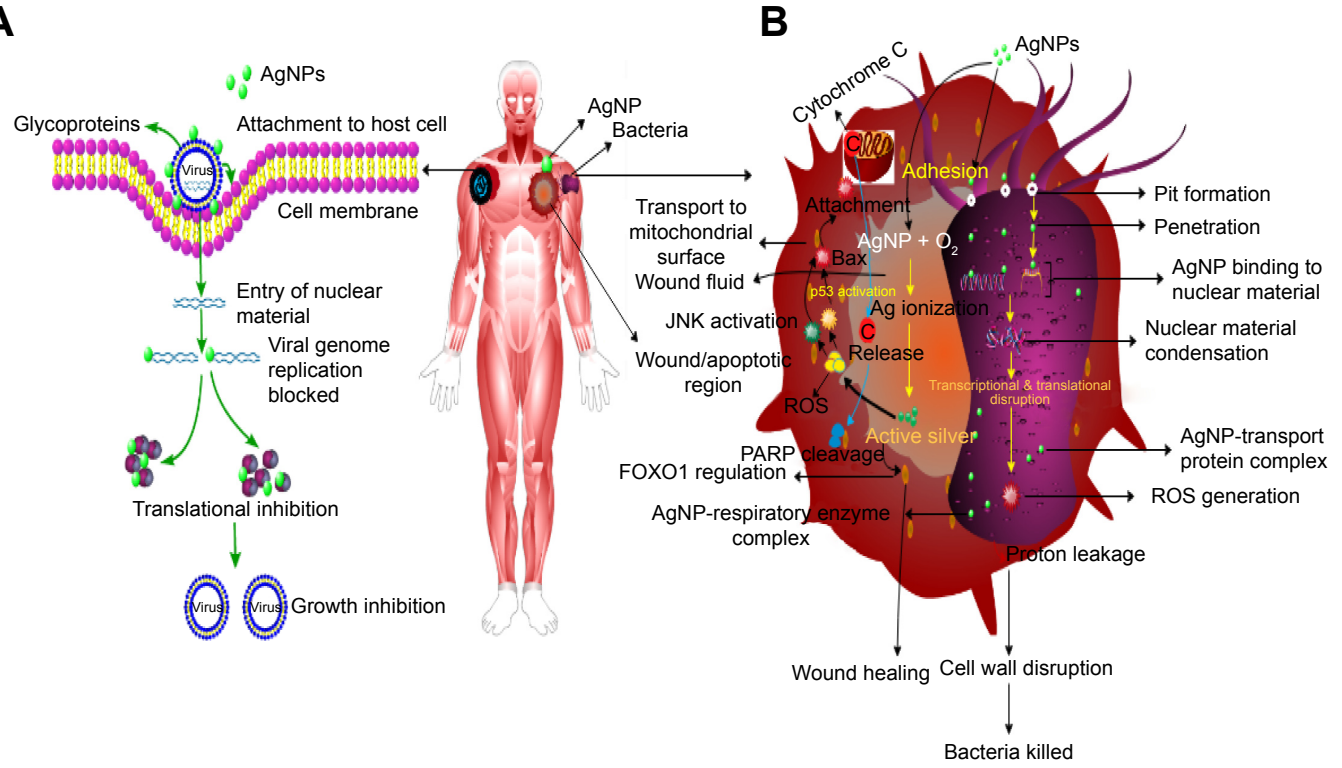

Figure 6 Mechanism of action of AgNPs in a biological system. (A) AgNPs antiviral mechanism. After attachment to host cell, the virus inserts its genetic material into the cell. Silver particles bind to the genetic material and block its replication which ultimately leads to translational inhibition, and in this way, viral growth is inhibited. (B) Wound healing and antibacterial mechanism of AgNPs. Although not reported in the literature, we assume that AgNPs may react with free oxygen in the wound portion followed by its ionization. This ionized active silver may regulate FOXOI which is a transcription factor stimulating wound healing molecule, TGF- $\beta$ I. Furthermore, active silver has also been reported to generate ROS. In the eukaryotic system, the ROS activate JNK and p53 proteins which induce Bax proteins to migrate to the mitochondrial surface resulting in cytochrome $C$ release from mitochondria which subsequently results in PARP cleavage. This phenomenon leads to apoptosis. The antibacterial mechanism of AgNPs starts with adhesion of AgNPs to bacterial cell followed by pit formation through which AgNPs enter the cell. These AgNPs then bind to nuclear material residing inside the bacteria. This leads to transcriptional and translational disruption and subsequently leads to ROS generation, which results in antibacterial activity. Abbreviations: AgNPs, silver nanoparticles; ROS, reactive oxygen species. 
disruption, thereby leading to the production of ROS as shown in Figure 6.

\section{Anticancer action}

The available literature about the anticancer potential of AgNPs strongly suggests that ROS generation is a result of the interaction of AgNPs with cancer cells. A study reported the anticancer potential of AgNPs against A549 and B16 cells. The interaction of AgNPs with A549 and B16 cells resulted in the production of superoxide anion $\left(\mathrm{O}^{\bullet-}\right)$ and hydrogen peroxide $\left(\mathrm{H}_{2} \mathrm{O}_{2}\right)$ species which arrested the uncontrolled cell division of the cancer cells. A plentitude of studies also suggests the antitumor activity of colloidal silver and gold nanoparticles on cancer cells due to the formation of ROS inside the cells. ${ }^{315-317}$ The increased formation of superoxide and hydrogen peroxide species also affects signal transduction pathways triggering apoptosis. ${ }^{318}$ Superoxide radicals also contribute to uncoupling of respiration with ATP synthesis. ${ }^{319}$

Another possible reason for cancer cells death is the release of silver ions from AgNPs because the concentration of silver ions determines cell death distinguishing between normal and cancer cells. ${ }^{320}$ Furthermore, the release of silver ions from AgNPs is also dependent on the $\mathrm{pH}$ of the medium (the lower the $\mathrm{pH}$, the higher the release of ions). It is well established that the $\mathrm{pH}$ of tumor cells is slightly acidic than normal cells. ${ }^{321}$

In tumor cells where the $\mathrm{pH}$ is slightly acidic than normal cells, AgNPs release more silver ions followed by formation of ROS leading to cancer cell death. However Asharani et al reported silver ions as a downstream signal of ROS. They reported that the interaction of AgNPs with cancer cells results in the generation of ROS followed by silver ions release form AgNPs through the oxidative dissolution process in acidic $\mathrm{pH}(5.0-6.4){ }^{322}$

\section{Cytotoxicity of AgNPs on normal cells}

Considering the distribution of AgNPs in multiple tissues, recent studies have revealed that cell types can influence responses to AgNPs. When fibroblast cells (NIH3T3) and colon cancer epithelial cells (HCT116) were exposed to AgNPs, the two types of cells showed distinct responses. ${ }^{323}$ For the fibroblast cells, exposure to AgNPs resulted in high expression of ROS and c-Jun N-terminal kinases, which activated mitochondrial apoptotic pathways. However, the epithelial cells showed less of a response to AgNPs because the expression of antiapoptotic protein bcl-2 was activated to protect against apoptotic stimuli. Starch-coated
AgNPs can cause different genotoxicities to fibroblast cells (IMR-90) and glioblastoma cells (U251). For both types of cells, AgNPs can diffuse into mitochondria and the nucleus, induce mitochondrial dysfunction, and increase the level of ROS, and subsequently cause DNA damage, chromosomal aberrations, and cell cycle arrest. However, fibroblast cells are more resistant to AgNPs, while the glioblastoma cells are more sensitive to AgNPs because fibroblast cells can recover from cell cycle arrest. ${ }^{324}$

Although AgNPs are widely used nanoparticles in the biomedical field, safety in the uses of AgNPs is still controversial. ${ }^{325}$ Conventional AgNPs had a strong affinity towards extracellular membranes and can accumulate in tissues in excess amount for a long time causing several toxic effects to normal cells. ${ }^{326}$ The most common effects of AgNPs had been observed on erythrocytes, where they can lyse the membrane ${ }^{327}$ and induce oxidative stressrelated responses such as induction of heme oxygenase I or formation of protein carbonyls. ${ }^{328}$ AgNPs and the ions released from the oxidized nanosilver surface directly bind to sulfur- and phosphorus-containing cellular constituents such as proteins and DNA, potentially causing damage to cellular machinery. ${ }^{234}$ The toxic effects of nanosilver on macrophages had been studied in the past. ${ }^{329}$ Upon uptake by the macrophage, silver metal could be further dissolved to $\mathrm{Ag}^{+}$ions in the lysosomes due to the lower $\mathrm{pH}$. Such $\mathrm{Ag}^{+}$ions are highly toxic to mitochondria and induce apoptosis. ${ }^{329}$ Moreover, AgNPs had been reported to be toxic to the liver, ${ }^{330}$ skin, ${ }^{331}$ lung, ${ }^{332}$ and neural cells. ${ }^{333}$ In conclusion, the AgNPs show toxic effects to all kinds of cells by interfering with their metabolic pathways, induction of apoptosis, and producing superoxides, genotoxicity, or other cytological consequences. However, there is still not enough data available to conclude what the toxic effects of AgNPs are due to the different sizes, shapes, and features of AgNPs. Therefore, extensive research is needed in this field to explore the proper mechanism of action of AgNPs in normal and carcinoma cell lines.

\section{Preparation of AgNPs to function in a specific tumor site}

Surface chemistry can influence the interaction of AgNPs with target tumor cells. The surface charges should be negative or neutral on AgNPs to target the specific tumor site. Also, the surface modification of AgNPs with a different biomarker of cancer can make them target the specific tumor site. The particle sizes are also a very important factor in targeting tumor site. ${ }^{334,335}$ 


\section{Antiviral mechanism}

During viral infection, the virus first comes in contact with the host cell and introduces its nuclear material through binding and fusion events into susceptible cells. Though the mechanism is not fully understood, AgNPs are assumed to interfere with this phenomenon by interacting with the viral surface glycoproteins in susceptible cells. Furthermore, AgNPs have also been reported to inhibit the post-entry stages of the HIV-1 life cycle, because AgNPs maintained their antiviral activity even after they were added to the cells already infected with HIV. The mechanism behind this event is that AgNPs may have blocked other functional HIV-1 proteins, and lessened reverse transcription rates through direct binding to sulfur and phosphorous groups of nuclear material. PVP-coated AgNPs efficiently inhibit respiratory syncytial virus (RSV) possibly by binding to evenly distributed surface glycoproteins on RSV virion's envelope. ${ }^{336}$ A different capping agent, namely mercaptoethanesulfonate, has been used for AgNPs tested against HSV- $1 .{ }^{298}$ Sulfonate-coated AgNPs either block the attachment and entry of HSV-1 virus into cell or cell-to-cell proliferation of the virus. Their anti-HSV-1 activity depends on their ability to mimic heparan sulfate (the cellular primary receptor for HSV) and thus compete with the virus for binding to the cell and is amplified by the presence of the inner core of nanosilver. The understanding of antiviral mechanism of AgNPs is still in its early stages; hence, further studies are needed to explore the mechanisms of action of AgNPs, which may render the conceivable antiviral development of AgNPs to fill the vital niche of a wide range of antiviral agents.

\section{Antifungal and antiprotozoal mechanism}

AgNPs may disrupt membrane integrity and inhibit normal budding process in yeast. As stated before, the AgNPs result in the generation of ROS, and the protozoans, viz. leishmania parasites, exhibit sensitivity to ROS. ${ }^{337}$ Studies related to antifungal and antiprotozoal activities of AgNPs are very rare, so further investigations are required to document the detailed antifungal and antiprotozoal mechanisms of AgNPs.

\section{Comparison of advantages and disadvantages of different synthesis methods}

Various routes are employed for the synthesis of AgNPs (Figure 1), and so we aimed to explore the merits and demerits of each above-mentioned method. Chemical synthesis is one of the important methods for AgNPs preparation. In chemical method, the major drawback is the use of highly deleterious organic solvents. These solvents have lower biocompatibility which limits their natural applications. ${ }^{25}$ In contrast, the physical techniques have no harmful substances employed during preparation of AgNPs, and thus uncontaminated and pure AgNPs can be obtained. ${ }^{116}$ Generally, physical methods are fast, and narrow-sized nanostructure formulations are produced which is another advantage of physical technique over chemical method. ${ }^{23,102}$ However, the use of furnace tubes in the physical method has some disadvantages such as consumption of high energy, $, 82,102,112$ and requirement of more time for thermal stability $22,111,112$ and more space. ${ }^{111,112}$

An advantage of biogenic methods over physical and chemical approaches is that they do not require deleterious solvents, while biopolymers play an important role as stabilizing and reducing agents. ${ }^{8,338}$ Green synthesis also has other advantages such as higher stability for longer time, ${ }^{338}$ and is facile, biocompatible, and cost-effective, and biogenically synthesized nanostructures have good applications in biomedical realm. Applications of biosynthesized AgNPs have been reviewed in many studies. ${ }^{25,339,340}$ Furthermore, it is very interesting that AgNPs produced by biosynthesis methods can be used in a lot of applications; however, the main disadvantage of these methods is purification. During purification procedure, there is a chance of bacterial contamination and transfection which may be considered as a major constraint in their biomedical applications. ${ }^{129}$

\section{Significance and toxicity of silver nanostructure}

Silver is considered as one of the most imperative metals which can be used in various fields, for instance, in magnetics, optics, and electronics. ${ }^{341}$ Besides these, it has also been used as an anticancer, antiviral, bactericidal, fungicidal, and antiprotozoal agent. ${ }^{342}$ It has been reported that low amount of silver has excessive potential against microorganisms, while the AgNPs at high concentration $(>10 \mu \mathrm{M})$ are toxic to mammals as well as host organisms. ${ }^{343}$ However, some reports demonstrated nanosilver as pharmaceutically sound and nontoxic to humans. ${ }^{342}$

Silver nanostructures have emergent role and versatility in various fields; however, some momentous evidence has also been reported in the literature regarding the toxicity of $\mathrm{Ag}$ nanostructures toward a number of hosts ranging from microorganisms to complex animals.

The AgNPs also inactivate microorganisms such as bacteria, algae, viruses, and fungi. Some metals like silver $(\mathrm{Ag})$, tellurium $(\mathrm{Te})$, and mercury $(\mathrm{Hg})$ are very toxic to the majority of bacteria and exhibit aberrant antimicrobial 
property even at small amount. ${ }^{344}$ Some reports have also proven the effective nature of AgNPs against fungi such as S. cerevisiae, ${ }^{345}$ algae such as Chlamydomonas reinhardtii, ${ }^{346}$ and viruses such as hepatitis B virus ${ }^{347}$ and HIV-1. ${ }^{348}$

The toxicity of silver nanostructure against complex organisms has also been reported in fish (zebrafish), ${ }^{349}$ humans, ${ }^{323,324}$ mice, rats, ${ }^{350,351}$ and Diptera spp. (Drosophila melanogaster). ${ }^{352}$ The detailed investigation of toxicity of $\mathrm{AgNO}_{3}$ can be found in some studies. ${ }^{26,320}$

\section{Miscellaneous applications of AgNPs}

Combination of nano- and metallic silver has been found to possess strong antimicrobial and antiparasitic properties. Hence, $\mathrm{AgNO}_{3}$ has been used in a wide range of applications in multiple disciplines. Silver has historical biomedical applications, such as silver foil, and $\mathrm{AgNO}_{3}$ sutures are used to prevent infections of surgical wounds, treat gonorrheal eye in newborns, repair vaginal tear after childbirth, and treat burns. ${ }^{344,353-356}$

Recently, AgNPs have displayed a tremendous cytotoxic effect against leukemia cells, ${ }^{357,358}$ breast cancer cells, ${ }^{359,360}$ hepatocellular carcinoma, and human liver HepG2 cells ${ }^{330,361}$ and lung cancer cells. ${ }^{362,363}$ Furthermore, AgNPs have been widely used in medical devices and consumer products such as surgical instruments, sterilizers, medical catheters, artificial teeth or orthodontics, bone coating, skin donation, creams, lotions, household sprays, home appliances, toys, detergents, toothpastes, soaps, containers for food storage and preservations, and antiseptic paints. ${ }^{364-370}$ Moreover, AgNPs have wide applications in electronics, such as data storage and optical devices, inks, nano- and optoelectronics, and nonlinear and sub-wavelength optics. ${ }^{368,371,372}$ Several investigators have demonstrated that AgNPs and silver composites possess the ability to catalyze chemical reactions, for example, oxidation of $\mathrm{CO},{ }^{373}$ oxidation of benzene to phenol, ${ }^{374}$ photodegradation of gaseous acetaldehyde, ${ }^{375}$ and reduction of p-nitrophenol to p-aminophenol. ${ }^{369}$ AgNPs have sensing applications in DNA sequencing ${ }^{376}$ and also play an important role in water filtration. ${ }^{1,377}$ The detailed application of AgNPs is demonstrated in Figure 1.

\section{Conclusion and future remarks}

From the forgone discussion, it can be concluded that AgNPs have gained remarkable interest, as they possess a wide range of applications in different fields including material science, biotechnology, and environmental and medical fields. Attributable to their distinctive physiochemical properties, AgNPs have been extensively used against bacteria, fungi, virus, leishmania, malaria, and neoplastic cells. Moreover, AgNPs have been prepared by different procedures such as chemical, physical, and biological methods. In biosynthetic methods, the potential of nature-gifted environmental-friendly reducers and stabilizers has been explored. The biogenic method is considered eco-friendly and handy to be applied in various realms, for instance, medical, cosmetic, and pharmaceutical fields. There still exist some open questions regarding silver-based nanotechnology, and each synthetic method has critical limitations which require special attention to eradicate. Furthermore, the toxic effects of AgNPs targeting from microorganisms to higher organisms including human is another interesting aspect that has also been outlined in this review.

Although reports regarding the potential of AgNPs against cancer, malaria and leishmania, and other human diseases are available, it will be a great revolution to find out the potential role of AgNPs against world's leading diseases with high mortality like AIDs and chronic hepatitis, which still need proper treatment. The biological systems including bacteria, fungi, and plants maintain a tight regulation of various metabolic machineries such as photosynthesis, respiration, and transport mechanism for several ions across membranes, and cell architecture (organization of lipids and proteins in the cell membrane and other endomembranes and cell wall). How AgNPs could take a promising part in regulating these metabolic pathways operating simultaneously will be an interesting facet of AgNPs mechanism of action which awaits elucidation. Furthermore, as evident from many studies, cancer cells use glucose, glutamine, asparagine (in some cases), lipids, and proteins as fuels for their uncontrolled proliferation. Now the question is whether AgNPs prevent the growth of cancer cells either by activation of the expression of glucosidase, lipase, or proteinase enzymes or by clinging to the mitotic and meiotic apparatus during cell division to block the whole metabolic machinery of the abnormal cells. For a certain type of cancer like acute lymphoblastic leukemia where asparagine is the main nutrient reservoir, if AgNPs control its levels by regulating the expression of L-asparaginase, then $\mathrm{pH}$ change (ie, from neutral to acidic) of the medium (blood) would occur which could cause hindrance to the cancer cell proliferation. In short, in-depth handy mechanistic studies are required to fill these gaps.

\section{Acknowledgments}

The author S Ullah Khan has been supported by the Chinese Scholarship Council for his PhD study. TA Saleh would like to acknowledge the support and funding provided by 
King Fahd University of Petroleum \& Minerals (KFUPM) through Project No IN161011 and No IN131053 under the Deanship of Research. The authors also thank Dr Nawshad Muhammad and Usman Ali for their critical reading of the manuscript, and U Ali who did some artwork in the manuscript.

\section{Disclosure}

The authors report no conflicts of interest in this work.

\section{References}

1. Gong P, Li H, He X, et al. Preparation and antibacterial activity of $\mathrm{Fe}_{3} \mathrm{O}_{4} @$ Ag nanoparticles. Nanotechnology.2007;18(28):285604.

2. Taniguchi N. On the Basic Concept of Nanotechnology: Proceedings of the International Conference on Production Engineering, 1974, Tokyo. Part II. Tokyo: Japan Society of Precision Engineering; 1974.

3. Fox CL Jr, Modak SM. Mechanism of silver sulfadiazine action on burn wound infections. Antimicrob Agents Chemother. 1974;5(6):582-588.

4. Gurunathan S, Han JW, Kwon DN, Kim JH. Enhanced antibacterial and anti-biofilm activities of silver nanoparticles against Gram-negative and Gram-positive bacteria. Nanoscale Res Lett. 2014;9(1):373.

5. Butler KS, Peeler DJ, Casey BJ, Dair BJ, Elespuru RK. Silver nanoparticles: correlating nanoparticle size and cellular uptake with genotoxicity. Mutagenesis. 2015;30(4):577-591.

6. Duran N, Marcato PD. Nanobiotechnology perspectives. Role of nanotechnology in the food industry: a review. Int J Food Sci Technol. 2013;48(6):1127-1134.

7. Rai M, Ingle A. Role of nanotechnology in agriculture with special reference to management of insect pests. Appl Microbiol Biotechnol. 2012;94(2):287-293.

8. Wei L, Lu J, Xu H, Patel A, Chen Z-S, Chen G. Silver nanoparticles: synthesis, properties, and therapeutic applications. Drug Discov Today. 2015;20(5):595-601

9. Malachová K, Praus P, Rybková Z, Kozák O. Antibacterial and antifungal activities of silver, copper and zinc montmorillonites. Appl Clay Sci. 2011;53(4):642-645.

10. Gu H, Ho P, Tong E, Wang L, Xu B. Presenting vancomycin on nanoparticles to enhance antimicrobial activities. Nano Lett. 2003;3(9): 1261-1263.

11. Cao X, Ye Y, Liu S. Gold nanoparticle-based signal amplification for biosensing. Anal Biochem. 2011;417(1):1-16.

12. Ahmad Z, Pandey R, Sharma S, Khuller G. Alginate nanoparticles as antituberculosis drug carriers: formulation development, pharmacokinetics and therapeutic potential. Indian J Chest Dis Allied Sci. 2006; 48(3):171-176.

13. Rathi Sre PR, Reka M, Poovazhagi R, Arul Kumar M, Murugesan K. Antibacterial and cytotoxic effect of biologically synthesized silver nanoparticles using aqueous root extract of Erythrina indica lam. Spectrochim Acta A Mol Biomol Spectrosc. 2015;135:1137-1144.

14. Manikandan R, Manikandan B, Raman T, et al. Biosynthesis of silver nanoparticles using ethanolic petals extract of Rosa indica and characterization of its antibacterial, anticancer and anti-inflammatory activities. Spectrochim Acta A Mol Biomol Spectrosc. 2015;138:120-129.

15. Mohammed Fayaz A, Ao Z, Girilal M, et al. Inactivation of microbial infectiousness by silver nanoparticles-coated condom: a new approach to inhibit HIV- and HSV-transmitted infection. Int J Nanomedicine. 2012;7: 5007-5018.

16. Adhikari U, Ghosh A, Chandra G. Nano particles of herbal origin: a recent eco-friend trend in mosquito control. Asian Pac J Trop Dis. 2013; 3(2):167-168.

17. Bindhu MR, Umadevi M. Antibacterial and catalytic activities of green synthesized silver nanoparticles. Spectrochim Acta A Mol Biomol Spectrosc. 2015;135:373-378.
18. Subarani S, Sabhanayakam S, Kamaraj C. Studies on the impact of biosynthesized silver nanoparticles (AgNPs) in relation to malaria and filariasis vector control against Anopheles stephensi Liston and Culex quinquefasciatus Say (Diptera: Culicidae). Parasitol Res. 2013;112(2): 487-499.

19. Elangovan K, Elumalai D, Anupriya S, Shenbhagaraman R, Kaleena P, Murugesan K. Phyto mediated biogenic synthesis of silver nanoparticles using leaf extract of Andrographis echioides and its bio-efficacy on anticancer and antibacterial activities. $J$ Photochem Photobiol B. 2015;151:118-124.

20. Roldán MV, Pellegri N, de Sanctis O. Electrochemical method for Ag-PEG nanoparticles synthesis. J Nanopart. 2013;2013:524150.

21. Sotiriou GA, Teleki A, Camenzind A, et al. Nanosilver on nanostructured silica: antibacterial activity and $\mathrm{Ag}$ surface area. Chem Eng $J$. 2011;170(2-3):547-554.

22. Ge L, Li Q, Wang M, Ouyang J, Li X, Xing MM. Nanosilver particles in medical applications: synthesis, performance, and toxicity. Int $J$ Nanomed. 2014;9:2399-2407.

23. Asanithi P, Chaiyakun S, Limsuwan P. Growth of silver nanoparticles by DC magnetron sputtering. J Nanomater. 2012;2012:963609.

24. Li G, He D, Qian Y, et al. Fungus-mediated green synthesis of silver nanoparticles using Aspergillus terreus. Int J Mol Sci. 2011;13(1):466-476.

25. Park Y. New paradigm shift for the green synthesis of antibacterial silver nanoparticles utilizing plant extracts. Toxicol Res. 2014;30(3): $169-178$.

26. Mashwani ZU, Khan T, Khan MA, Nadhman A. Synthesis in plants and plant extracts of silver nanoparticles with potent antimicrobial properties: current status and future prospects. Appl Microbiol Biotechnol. 2015;99(23):9923-9934.

27. Singh R, Wagh P, Bellare J, et al. Synthesis, optimization, and characterization of silver nanoparticles from Acinetobacter calcoaceticus and their enhanced antibacterial activity when combined with antibiotics. Int J Nanomedicine. 2013;8:4277-4290.

28. Karthik C, Radha K. Biosynthesis and characterization of silver nanoparticles using Enterobacter aerogenes: a kinetic approach. Dig $J$ Nanomater Biostruct. 2012;7(3):1007-1014.

29. Kalpana D, Lee YS. Synthesis and characterization of bactericidal silver nanoparticles using cultural filtrate of simulated microgravity grown Klebsiella pneumoniae. Enzyme Microb Technol. 2013;52(3): $151-156$.

30. Samadi N, Golkaran D, Eslamifar A, Jamalifar H, Fazeli MR, Mohseni FA. Intra/extracellular biosynthesis of silver nanoparticles by an autochthonous strain of Proteus mirabilis isolated from photographic waste. J Biomed Nanotechnol. 2009;5(3):247-253.

31. Debabov V, Voeikova T, Shebanova A, et al. Bacterial synthesis of silver sulfide nanoparticles. Nanotechnol Russ. 2013;8(3-4):269-276.

32. Oves M, Khan MS, Zaidi A, et al. Antibacterial and cytotoxic efficacy of extracellular silver nanoparticles biofabricated from chromium reducing novel OS4 strain of Stenotrophomonas maltophilia. PLoS One. 2013;8(3):e59140.

33. Rajeshkumar S, Malarkodi C, Paulkumar K, Vanaja M, Gnanajobitha G, Annadurai G. Intracellular and extracellular biosynthesis of silver nanoparticles by using marine bacteria Vibrio alginolyticus. Nanosci Nanotechnol. 2013;3(1):21-25.

34. Sriram MI, Kalishwaralal K, Gurunathan S. Biosynthesis of silver and gold nanoparticles using Bacillus licheniformis. Methods Mol Biol. 2012;906:33-43

35. Kalishwaralal K, Deepak V, Pandian SRK, et al. Biosynthesis of silver and gold nanoparticles using Brevibacterium casei. Colloids Surf B Biointerfaces. 2010;77(2):257-262.

36. Tamboli DP, Lee DS. Mechanistic antimicrobial approach of extracellularly synthesized silver nanoparticles against gram positive and gram negative bacteria. J Hazard Mater. 2013;260:878-884.

37. Otari SV, Patil RM, Nadaf NH, Ghosh SJ, Pawar SH. Green synthesis of silver nanoparticles by microorganism using organic pollutant: its antimicrobial and catalytic application. Environ Sci Pollut Res. 2014; 21(2):1503-1513. 
38. Deepa S, Kanimozhi K, Panneerselvam A. Antimicrobial activity of extracellularly synthesized silver nanoparticles from marine derived actinomycetes. Int J Curr Microbiol Appl Sci. 2013;2(9):223-230.

39. Banu AN, Balasubramanian C, Moorthi PV. Biosynthesis of silver nanoparticles using Bacillus thuringiensis against dengue vector, Aedes aegypti (Diptera: Culicidae). Parasitol Res. 2014;113(1):311-316.

40. Abdel-Aziz MS, Shaheen MS, El-Nekeety AA, Abdel-Wahhab MA. Antioxidant and antibacterial activity of silver nanoparticles biosynthesized using Chenopodium murale leaf extract. J Saudi Chem Soc. 2014;18(4):356-363.

41. Parveen M, Ahmad F, Malla AM, Azaz S. Microwave-assisted green synthesis of silver nanoparticles from Fraxinus excelsior leaf extract and its antioxidant assay. Appl Nanosci. 2016;6(2):267-276.

42. Sujitha V, Murugan K, Paulpandi M, et al. Green-synthesized silver nanoparticles as a novel control tool against dengue virus (DEN-2) and its primary vector Aedes aegypti. Parasitol Res. 2015;114(9): 3315-3325.

43. Roni M, Murugan K, Panneerselvam C, et al. Characterization and biotoxicity of Hypnea musciformis-synthesized silver nanoparticles as potential eco-friendly control tool against Aedes aegypti and Plutella xylostella. Ecotoxicol Environ Saf. 2015;121:31-38.

44. Gogoi N, Babu PJ, Mahanta C, Bora U. Green synthesis and characterization of silver nanoparticles using alcoholic flower extract of Nyctanthes arbortristis and in vitro investigation of their antibacterial and cytotoxic activities. Mater Sci Eng C Mater Biol Appl. 2015;46: 463-469.

45. Nadagouda MN, Iyanna N, Lalley J, Han C, Dionysiou DD, Varma RS. Synthesis of silver and gold nanoparticles using antioxidants from blackberry, blueberry, pomegranate, and turmeric extracts. ACS Sustainable Chem Eng. 2014;2(7):1717-1723.

46. Ajitha B, Reddy YAK, Reddy PS. Green synthesis and characterization of silver nanoparticles using Lantana camara leaf extract. Mater Sci Eng C. 2015;49:373-381.

47. Lallawmawma H, Sathishkumar G, Sarathbabu S, et al. Synthesis of silver and gold nanoparticles using Jasminum nervosum leaf extract and its larvicidal activity against filarial and arboviral vector Culex quinquefasciatus Say (Diptera: Culicidae). Environ Sci Pollut Res Int. 2015; 22(22):17753-17768

48. Gupta K, Hazarika SN, Saikia D, Namsa ND, Mandal M. One step green synthesis and anti-microbial and anti-biofilm properties of Psidium guajava L. leaf extract-mediated silver nanoparticles. Mater Lett. 2014;125:67-70.

49. Vidhu VK, Philip D. Spectroscopic, microscopic and catalytic properties of silver nanoparticles synthesized using Saraca indica flower. Spectrochim Acta A Mol Biomol Spectrosc. 2014;117:102-108.

50. Suganya G, Karthi S, Shivakumar MS. Larvicidal potential of silver nanoparticles synthesized from Leucas aspera leaf extracts against dengue vector Aedes aegypti. Parasitol Res. 2014;113(5):1673-1679.

51. Muniyappan N, Nagarajan N. Green synthesis of silver nanoparticles with Dalbergia spinosa leaves and their applications in biological and catalytic activities. Process Biochem. 2014;49(6):1054-1061.

52. Kahrilas GA, Wally LM, Fredrick SJ, Hiskey M, Prieto AL, Owens JE. Microwave-assisted green synthesis of silver nanoparticles using orange peel extract. ACS Sustainable Chem Eng. 2013;2(3):367-376.

53. Arokiyaraj S, Arasu MV, Vincent S, et al. Rapid green synthesis of silver nanoparticles from Chrysanthemum indicum L and its antibacterial and cytotoxic effects: an in vitro study. Int J Nanomedicine. 2014;9: 379-388.

54. Murugan K, Senthilkumar B, Senbagam D, Al-Sohaibani S. Biosynthesis of silver nanoparticles using Acacia leucophloea extract and their antibacterial activity. Int J Nanomedicine. 2014;9:2431-2438.

55. Nithya Deva Krupa A, Raghavan V. Biosynthesis of silver nanoparticles using Aegle marmelos (Bael) fruit extract and its application to prevent adhesion of bacteria: a strategy to control microfouling. Bioinorg Chem Appl. 2014;2014:949538.

56. Joseph S, Mathew B. Microwave assisted biosynthesis of silver nanoparticles using the rhizome extract of Alpinia galanga and evaluation of their catalytic and antimicrobial activities. J Nanopart. 2014;2014:967802.
57. Ganaie S, Abbasi T, Abbasi S. Rapid and green synthesis of bimetallic $\mathrm{Au}-\mathrm{Ag}$ nanoparticles using an otherwise worthless weed Antigonon leptopus. J Exp Nanosci. 2016;11(6):395-417.

58. Gurunathan S, Jeong JK, Han JW, Zhang XF, Park JH, Kim JH. Multidimensional effects of biologically synthesized silver nanoparticles in Helicobacter pylori, Helicobacter felis, and human lung (L132) and lung carcinoma A549 cells. Nanoscale Res Lett. 2015;10(1):35.

59. Jeeva K, Thiyagarajan M, Elangovan V, Geetha N, Venkatachalam P. Caesalpinia coriaria leaf extracts mediated biosynthesis of metallic silver nanoparticles and their antibacterial activity against clinically isolated pathogens. Ind Crops Prod. 2014;52:714-720.

60. Parveen A, Rao S. Cytotoxicity and genotoxicity of biosynthesized gold and silver nanoparticles on human cancer cell lines. J Clust Sci. 2015;26(3):775-788.

61. Peddi SP, Sadeh BA. Structural studies of silver nanoparticles obtained through single-step green synthesis. Mater Sci Eng. 2015;92:1-8.

62. Ammar HA, El-Desouky TA. Green synthesis of nanosilver particles by Aspergillus terreus $\mathrm{HA} 1 \mathrm{~N}$ and Penicillium expansum $\mathrm{HA} 2 \mathrm{~N}$ and its antifungal activity against mycotoxigenic fungi. $J$ Appl Microbiol. 2016;121(1):89-100.

63. Lima R, Feitosa LO, Ballottin D, Marcato PD, Tasic L, Durán N. Cytotoxicity and genotoxicity of biogenic silver nanoparticles. J Phys Conf Ser. 2013;429(1):012020-1-012020-8.

64. Dar MA, Ingle A, Rai M. Enhanced antimicrobial activity of silver nanoparticles synthesized by Cryphonectria sp. evaluated singly and in combination with antibiotics. Nanomedicine. 2013;9(1):105-110.

65. Salunkhe RB, Patil SV, Patil CD, Salunke BK. Larvicidal potential of silver nanoparticles synthesized using fungus Cochliobolus lunatus against Aedes aegypti (Linnaeus, 1762) and Anopheles stephensi Liston (Diptera; Culicidae). Parasitol Res. 2011;109(3):823-831.

66. Bawaskar M, Gaikwad S, Ingle A, et al. A new report on mycosynthesis of silver nanoparticles by Fusarium culmorum. Curr Nanosci. 2010;6(4):376-380.

67. Raheman F, Deshmukh S, Ingle A, Gade A, Rai M. Silver nanoparticles: novel antimicrobial agent synthesized from an endophytic fungus Pestalotia sp. isolated from leaves of Syzygium cumini (L). Nano Biomed Eng. 2011;3(3):174-178.

68. Birla SS, Tiwari VV, Gade AK, Ingle AP, Yadav AP, Rai MK. Fabrication of silver nanoparticles by Phoma glomerata and its combined effect against Escherichia coli, Pseudomonas aeruginosa and Staphylococcus aureus. Lett Appl Microbiol. 2009;48(2):173-179.

69. Jaidev LR, Narasimha G. Fungal mediated biosynthesis of silver nanoparticles, characterization and antimicrobial activity. Colloids Surf B Biointerfaces. 2010;81(2):430-433.

70. Govindaraju K, Basha SK, Kumar VG, Singaravelu G. Silver, gold and bimetallic nanoparticles production using single-cell protein (Spirulina platensis) Geitler. J Mater Sci. 2008;43(15):5115-5122.

71. Tsuji T, Kakita T, Tsuji M. Preparation of nano-size particles of silver with femtosecond laser ablation in water. Appl Surf Sci. 2003; 206(1-4):314-320.

72. Siegel J, Kvítek O, Ulbrich P, Kolská Z, Slepička P, Švorčík V. Progressive approach for metal nanoparticle synthesis. Mater Lett. 2012; 89:47-50.

73. Kim D, Jeong S, Moon J. Synthesis of silver nanoparticles using the polyol process and the influence of precursor injection. Nanotechnology. 2006;17(16):4019-4024.

74. Ashkarran AA. A novel method for synthesis of colloidal silver nanoparticles by arc discharge in liquid. Curr Appl Phys. 2010;10(6): 1442-1447.

75. Jin R, Cao YC, Hao E, Métraux GS, Schatz GC, Mirkin CA. Controlling anisotropic nanoparticle growth through plasmon excitation. Nature. 2003;425(6957):487-490.

76. Huang L, Zhai ML, Long DW, et al. UV-induced synthesis, characterization and formation mechanism of silver nanoparticles in alkalic carboxymethylated chitosan solution. J Nanopart Res. 2008;10(7):1193-1202.

77. Johans C, Clohessy J, Fantini S, Kontturi K, Cunnane VJ. Electrosynthesis of polyphenylpyrrole coated silver particles at a liquid-liquid interface. Electrochem Commun. 2002;4(3):227-230. 
78. Ma H, Yin B, Wang S, et al. Synthesis of silver and gold nanoparticles by a novel electrochemical method. ChemPhysChem. 2004;5(1):68-75.

79. Rogers JV, Parkinson CV, Choi YW, Speshock JL, Hussain SM. A preliminary assessment of silver nanoparticle inhibition of monkeypox virus plaque formation. Nanoscale Res Lett. 2008;3(4):129-133.

80. Liu J, Huang Z, Cai K, et al. Clean synthesis of an economical 3D nanochain network of $\mathrm{PdCu}$ alloy with enhanced electrocatalytic performance towards ethanol oxidation. Chemistry. 2015;21(49):17779-17785.

81. Ponnuvel S, Subramanian B, Ponnuraj K. Conformational change results in loss of enzymatic activity of jack bean urease on its interaction with silver nanoparticle. Protein J. 2015;34(5):329-337.

82. Karthikeyan J, Nila K, Thooyavan G, Vimalkumar E. Larvicidal and antibacterial efficacy of green synthesised silver nanoparticles using Melia dubia. Int J Pharm Pharm Sci. 2014;6(7):395-399.

83. Banerjee P, Satapathy M, Mukhopahayay A, Das P. Leaf extract mediated green synthesis of silver nanoparticles from widely available Indian plants: synthesis, characterization, antimicrobial property and toxicity analysis. Bioresour Bioprocess. 2014;1(1):3.

84. Sinha SN, Paul D. Phytosynthesis of silver nanoparticles using andrographis paniculata leaf extract and evaluation of their antibacterial activities. Spectrosc Lett. 2015;48(8):600-604.

85. Mubayi A, Chatterji S, Rai PM, Watal G. Evidence based green synthesis of nanoparticles. Adv Mater Lett. 2012;3(6):519-525.

86. Safaepour M, Shahverdi AR, Shahverdi HR, Khorramizadeh MR, Gohari AR. Green synthesis of small silver nanoparticles using geraniol and its cytotoxicity against fibrosarcoma-wehi 164. Avicenna J Med Biotechnol. 2009;1(2):111-115.

87. Raghunandan D, Mahesh BD, Basavaraja S, Balaji S, Manjunath S, Venkataraman A. Microwave-assisted rapid extracellular synthesis of stable bio-functionalized silver nanoparticles from guava (Psidium guajava) leaf extract. J Nanopart Res. 2011;13(5):2021-2028.

88. Suman T, Rajasree SR, Kanchana A, Elizabeth SB. Biosynthesis, characterization and cytotoxic effect of plant mediated silver nanoparticles using Morinda citrifolia root extract. Colloids Surf B Biointerfaces 2013;106:74-78.

89. Borase HP, Patil CD, Suryawanshi RK, Patil SV. Ficus carica latexmediated synthesis of silver nanoparticles and its application as a chemophotoprotective agent. Appl Biochem Biotechnol. 2013;171(3): 676-688.

90. Valodkar M, Jadeja RN, Thounaojam MC, Devkar RV, Thakore S. In vitro toxicity study of plant latex capped silver nanoparticles in human lung carcinoma cells. Mater Sci Eng C. 2011;31(8):1723-1728.

91. Gengan RM, Anand K, Phulukdaree A, Chuturgoon A. A549 lung cell line activity of biosynthesized silver nanoparticles using Albizia adianthifolia leaf. Colloids Surf B Biointerfaces. 2013;105:87-91.

92. Zhang Q, Li N, Goebl J, Lu Z, Yin Y. A systematic study of the synthesis of silver nanoplates: is citrate a "magic" reagent? J Am Chem Soc. 2011;133(46):18931-18939.

93. Sotiriou GA, Pratsinis SE. Antibacterial activity of nanosilver ions and particles. Environ Sci Technol. 2010;44(14):5649-5654.

94. Moore K. A new silver dressing for wounds with delayed healing. Wounds UK. 2006;2(2):70.

95. Evanoff DD Jr, Chumanov G. Synthesis and optical properties of silver nanoparticles and arrays. ChemPhysChem. 2005;6(7):1221-1231.

96. Pyatenko A, Yamaguchi M, Suzuki M. Synthesis of spherical silver nanoparticles with controllable sizes in aqueous solutions. $J$ Phys Chem C. 2007;111(22):7910-7917.

97. Blanco-Andujar C, Tung LD, Thanh NT. Synthesis of nanoparticles for biomedical applications. Annu Rep Sect A Inorg Chem. 2010;106 553-568.

98. Wiley B, Sun Y, Mayers B, Xia Y. Shape-controlled synthesis of metal nanostructures: the case of silver. Chemistry. 2005;11(2):454-463.

99. Evanoff DD, Chumanov G. Size-controlled synthesis of nanoparticles. 2. Measurement of extinction, scattering, and absorption cross sections J Phys Chem B. 2004;108(37):13957-13962.

100. Merga G, Wilson R, Lynn G, Milosavljevic BH, Meisel D. Redox catalysis on "naked" silver nanoparticles. JPhys Chem C. 2007;111(33): $12220-12226$.
101. Chen J, Ouyang J, Kong J, Zhong W, Xing MM. Photo-cross-linked and $\mathrm{pH}$-sensitive biodegradable micelles for doxorubicin delivery. ACS Appl Mater Interfaces. 2013;5(8):3108-3117.

102. Iravani S, Korbekandi H, Mirmohammadi S, Zolfaghari B. Synthesis of silver nanoparticles: chemical, physical and biological methods. Res Pharm Sci. 2014;9(6):385-406.

103. Tien D, Liao C, Huang J, et al. Novel technique for preparing a nanosilver water suspension by the arc-discharge method. Rev Adv Mater Sci. 2008;18:750-756.

104. Zhang Y, Peng H, Huang W, Zhou Y, Yan D. Facile preparation and characterization of highly antimicrobial colloid Ag or Au nanoparticles. J Colloid Interface Sci. 2008;325(2):371-376.

105. Zhang Y, Chen F, Zhuang J, et al. Synthesis of silver nanoparticles via electrochemical reduction on compact zeolite film modified electrodes. Chem Commun. 2002;(23):2814-2815.

106. Abid JP, Wark AW, Brevet PF, Girault HH. Preparation of silver nanoparticles in solution from a silver salt by laser irradiation. Chem Commun (Camb). 2002;(7):792-793.

107. Sudeep P, Kamat PV. Photosensitized growth of silver nanoparticles under visible light irradiation: a mechanistic investigation. Chem Mater. 2005;17(22):5404-5410.

108. El-Nour KMA, Eftaiha A, Al-Warthan A, Ammar RA. Synthesis and applications of silver nanoparticles. Arab J Chem. 2010;3(3):135-140.

109. Tien DC, Tseng KH, Liao CY, Huang JC, Tsung TT. Discovery of ionic silver in silver nanoparticle suspension fabricated by arc discharge method. J Alloys Compounds. 2008;463(1-2):408-411.

110. Kosmala A, Wright R, Zhang Q, Kirby P. Synthesis of silver nano particles and fabrication of aqueous Ag inks for inkjet printing. Mater Chem Phys. 2011;129(3):1075-1080.

111. Kruis FE, Fissan H, Rellinghaus B. Sintering and evaporation characteristics of gas-phase synthesis of size-selected $\mathrm{PbS}$ nanoparticles. Mater Sci Eng B. 2000;69:329-334.

112. Magnusson MH, Deppert K, Malm JO, Bovin JO, Samuelson L. Gold nanoparticles: production, reshaping, and thermal charging. J Nanopart Res. 1999;1(2):243-251.

113. Kabashin AV, Meunier M. Synthesis of colloidal nanoparticles during femtosecond laser ablation of gold in water. J Appl Phys. 2003; 94(12):7941-7943.

114. Sylvestre JP, Kabashin AV, Sacher E, Meunier M, Luong JH. Stabilization and size control of gold nanoparticles during laser ablation in aqueous cyclodextrins. J Am Chem Soc. 2004;126(23):7176-7177.

115. Dolgaev S, Simakin A, Voronov V, Shafeev GA, Bozon-Verduraz F. Nanoparticles produced by laser ablation of solids in liquid environment. Appl Surf Sci. 2002;186(1-4):546-551.

116. Tsuji T, Iryo K, Watanabe N, Tsuji M. Preparation of silver nanoparticles by laser ablation in solution: influence of laser wavelength on particle size. Appl Surf Sci. 2002;202(1-2):80-85.

117. Huang H, Yang Y. Preparation of silver nanoparticles in inorganic clay suspensions. Compos Sci Technol. 2008;68(14):2948-2953.

118. Zhou Y, Yu SH, Wang CY, Li XG, Zhu YR, Chen ZY. A novel ultraviolet irradiation photoreduction technique for the preparation of single-crystal Ag nanorods and Ag dendrites. Adv Mater. 1999;11(10): $850-852$.

119. Tao G, Liu L, Wang Y, et al. Characterization of silver nanoparticle in situ synthesis on porous sericin gel for antibacterial application. J Nanomater. 2016;2016:9505704.

120. Socol Y, Abramson O, Gedanken A, Meshorer Y, Berenstein L, Zaban A. Suspensive electrode formation in pulsed sonoelectrochemical synthesis of silver nanoparticles. Langmuir. 2002;18(12):4736-4740.

121. Naik RR, Stringer SJ, Agarwal G, Jones SE, Stone MO. Biomimetic synthesis and patterning of silver nanoparticles. Nat Mater. 2002; 1(3):169-172.

122. Anisha BS, Biswas R, Chennazhi KP, Jayakumar R. Chitosan-hyaluronic $\mathrm{acid} /$ nano silver composite sponges for drug resistant bacteria infected diabetic wounds. Int J Biol Macromol. 2013;62:310-320.

123. Shivaji S, Madhu S, Singh S. Extracellular synthesis of antibacterial silver nanoparticles using psychrophilic bacteria. Process Biochem. 2011;46(9):1800-1807. 
124. Sintubin L, De Windt W, Dick J, et al. Lactic acid bacteria as reducing and capping agent for the fast and efficient production of silver nanoparticles. Appl Microbiol Biotechnol. 2009;84(4):741-749.

125. Jung JH, Oh HC, Noh HS, Ji JH, Kim SS. Metal nanoparticle generation using a small ceramic heater with a local heating area. J Aerosol Sci. 2006;37(12):1662-1670.

126. Balaji DS, Basavaraja S, Deshpande R, Mahesh DB, Prabhakar BK, Venkataraman A. Extracellular biosynthesis of functionalized silver nanoparticles by strains of Cladosporium cladosporioides fungus. Colloids Surf B Biointerfaces. 2009;68(1):88-92.

127. Bhattacharya D, Gupta RK. Nanotechnology and potential of microorganisms. Crit Rev Biotechnol. 2005;25(4):199-204.

128. Mourato A, Gadanho M, Lino AR, Tenreiro R. Biosynthesis of crystalline silver and gold nanoparticles by extremophilic yeasts. Bioinorg Chem Appl. 2011;2011:546074.

129. Sintubin L, Verstraete W, Boon N. Biologically produced nanosilver: current state and future perspectives. Biotechnol Bioeng. 2012; 109(10):2422-2436.

130. Shankar SS, Ahmad A, Sastry M. Geranium leaf assisted biosynthesis of silver nanoparticles. Biotechnol Prog. 2003;19(6):1627-1631.

131. Mohanpuria P, Rana NK, Yadav SK. Biosynthesis of nanoparticles: technological concepts and future applications. J Nanopart Res. 2008; 10(3):507-517.

132. Iravani S. Green synthesis of metal nanoparticles using plants. Green Chem. 2011;13(10):2638-2650.

133. Elumalai E, Prasad T, Hemachandran J, Therasa SV, Thirumalai T, David E. Extracellular synthesis of silver nanoparticles using leaves of Euphorbia hirta and their antibacterial activities. J Pharm Sci Res. 2010;2(9):549-554.

134. Krishnaraj C, Jagan E, Rajasekar S, Selvakumar P, Kalaichelvan P, Mohan N. Synthesis of silver nanoparticles using Acalypha indica leaf extracts and its antibacterial activity against water borne pathogens. Colloids Surf B Biointerfaces. 2010;76(1):50-56.

135. Veerasamy R, Xin TZ, Gunasagaran S, et al. Biosynthesis of silver nanoparticles using mangosteen leaf extract and evaluation of their antimicrobial activities. J Saudi Chem Soc. 2011;15(2):113-120.

136. Singhal G, Bhavesh R, Kasariya K, Sharma AR, Singh RP. Biosynthesis of silver nanoparticles using Ocimum sanctum (Tulsi) leaf extract and screening its antimicrobial activity. J Nanopart Res. 2011; 13(7):2981-2988.

137. Sathishkumar M, Sneha K, Won S, Cho CW, Kim S, Yun YS. Cinnamon zeylanicum bark extract and powder mediated green synthesis of nano-crystalline silver particles and its bactericidal activity. Colloids Surf B Biointerfaces. 2009;73(2):332-338.

138. Huang J, Li Q, Sun D, et al. Biosynthesis of silver and gold nanoparticles by novel sundried Cinnamomum camphora leaf. Nanotechnology. 2007;18(10):105104.

139. Balashanmugam P, Balakumaran M, Murugan R, Dhanapal K, Kalaichelvan P. Phytogenic synthesis of silver nanoparticles, optimization and evaluation of in vitro antifungal activity against human and plant pathogens. Microbiol Res. 2016;192:52-64.

140. Chandran SP, Chaudhary M, Pasricha R, Ahmad A, Sastry M. Synthesis of gold nanotriangles and silver nanoparticles using Aloe vera plant extract. Biotechnol Prog. 2006;22(2):577-583.

141. Li S, Shen Y, Xie A, et al. Green synthesis of silver nanoparticles using Capsicum annuum L. extract. Green Chem. 2007;9(8):852-858.

142. Jain D, Daima HK, Kachhwaha S, Kothari SL. Synthesis of plantmediated silver nanoparticles using papaya fruit extract and evaluation of their anti-microbial activities. Dig J Nanomater Biostruct. 2009; 4(3):557-563.

143. Begum NA, Mondal S, Basu S, Laskar RA, Mandal D. Biogenic synthesis of $\mathrm{Au}$ and $\mathrm{Ag}$ nanoparticles using aqueous solutions of black tea leaf extracts. Colloids Surf B Biointerfaces. 2009;71(1): 113-118.

144. Song JY, Kim BS. Rapid biological synthesis of silver nanoparticles using plant leaf extracts. Bioprocess Biosyst Eng. 2009;32(1): 79-84.
145. Bar H, Bhui DK, Sahoo GP, Sarkar P, Pyne S, Misra A. Green synthesis of silver nanoparticles using seed extract of Jatropha curcas. Colloids Surf A Physicochem Eng Asp. 2009;348(1-3):212-216.

146. Sathishkumar M, Sneha K, Yun YS. Immobilization of silver nanoparticles synthesized using Curcuma longa tuber powder and extract on cotton cloth for bactericidal activity. Bioresour Technol. 2010;101(20): 7958-7965.

147. Babu SA, Prabu HG. Synthesis of AgNPs using the extract of Calotropis procera flower at room temperature. Mater Lett. 2011;65(11): 1675-1677.

148. Sun Q, Cai X, Li J, Zheng M, Chen Z, Yu CP. Green synthesis of silver nanoparticles using tea leaf extract and evaluation of their stability and antibacterial activity. Colloids Surf A Physicochem Eng Asp. 2014; 444:226-231.

149. Karatoprak GS, Aydin G, Altinsoy B, Altinkaynak C, Kosar M, Ocsoy I. The effect of Pelargonium endlicherianum Fenzl. root extracts on formation of nanoparticles and their antimicrobial activities. Enzyme Microb Technol. 2017;97:21-26.

150. Klaus T, Joerger R, Olsson E, Granqvist C-G. Silver-based crystalline nanoparticles, microbially fabricated. Proc Natl Acad Sci US A. 1999;96(24):13611-13614.

151. Parikh RY, Ramanathan R, Coloe PJ, et al. Genus-wide physicochemical evidence of extracellular crystalline silver nanoparticles biosynthesis by Morganella spp. PLoS One. 2011;6(6):e21401.

152. Brayner R, Barberousse H, Hemadi M, et al. Cyanobacteria as bioreactors for the synthesis of $\mathrm{Au}, \mathrm{Ag}, \mathrm{Pd}$, and Pt nanoparticles via an enzymemediated route. J Nanosci Nanotechnol. 2007;7(8):2696-2708.

153. Mouxing F, Qingbiao L, Daohua S, et al. Rapid preparation process of silver nanoparticles by bioreduction and their characterizations 11 supported by the National Natural Science Foundation of China (No. 20376076). Chin J Chem Eng. 2006;14(1):114-117.

154. Lengke MF, Fleet ME, Southam G. Biosynthesis of silver nanoparticles by filamentous cyanobacteria from a silver (I) nitrate complex. Langmuir. 2007;23(5):2694-2699.

155. Nair B, Pradeep T. Coalescence of nanoclusters and formation of submicron crystallites assisted by Lactobacillus strains. Cryst Growth Des. 2002;2(4):293-298.

156. Dhoondia ZH, Chakraborty H. Lactobacillus mediated synthesis of silver oxide nanoparticles. Nanomater Nanotechnol. 2012;2:15.

157. Kalishwaralal K, Deepak V, Ramkumarpandian S, Nellaiah H, Sangiliyandi G. Extracellular biosynthesis of silver nanoparticles by the culture supernatant of Bacillus licheniformis. Mater Lett. 2008; 62(29):4411-4413.

158. Kalimuthu K, Suresh Babu R, Venkataraman D, Bilal M, Gurunathan S. Biosynthesis of silver nanocrystals by Bacillus licheniformis. Colloids Surf B Biointerfaces. 2008;65(1):150-153.

159. Mokhtari N, Daneshpajouh S, Seyedbagheri S, et al. Biological synthesis of very small silver nanoparticles by culture supernatant of Klebsiella pneumonia: the effects of visible-light irradiation and the liquid mixing process. Mater Res Bull. 2009;44(6):1415-1421.

160. Korbekandi H, Iravani S, Abbasi S. Optimization of biological synthesis of silver nanoparticles using Lactobacillus casei subsp. casei. J Chem Technol Biotechnol. 2012;87(7):932-937.

161. Bhainsa KC, D'Souza SF. Extracellular biosynthesis of silver nanoparticles using the fungus Aspergillus fumigatus. Colloids Surf B Biointerfaces. 2006;47(2):160-164.

162. Ahmad A, Mukherjee P, Senapati S, et al. Extracellular biosynthesis of silver nanoparticles using the fungus Fusarium oxysporum. Colloids Surf B Biointerfaces. 2003;28(4):313-318.

163. Sadowski Z, Maliszewska I, Grochowalska B, Polowczyk I, Kozlecki T. Synthesis of silver nanoparticles using microorganisms. Mater Sci Poland. 2008;26(2):419-424.

164. Maliszewska I, Szewczyk K, Waszak K. Biological synthesis of silver nanoparticles. J Phys Conf Ser. 2009;146:2025.

165. Sanghi R, Verma P. Biomimetic synthesis and characterisation of protein capped silver nanoparticles. Bioresour Technol. 2009;100(1): 501-504. 
166. Vigneshwaran N, Ashtaputre N, Varadarajan P, Nachane R, Paralikar K, Balasubramanya R. Biological synthesis of silver nanoparticles using the fungus Aspergillus flavus. Mater Lett. 2007;61(6):1413-1418.

167. Venkatpurwar V, Pokharkar V. Green synthesis of silver nanoparticles using marine polysaccharide: study of in-vitro antibacterial activity. Mater Lett. 2011;65(6):999-1002.

168. El-Rafie H, El-Rafie MH, Zahran MK. Green synthesis of silver nanoparticles using polysaccharides extracted from marine macro algae. Carbohydr Polym. 2013;96(2):403-410.

169. Salari Z, Danafar F, Dabaghi S, Ataei SA. Sustainable synthesis of silver nanoparticles using macroalgae Spirogyra varians and analysis of their antibacterial activity. J Saudi Chem Soc. 2016;20(4):459-464.

170. Shahverdi AR, Minaeian S, Shahverdi HR, Jamalifar H, Nohi A-A. Rapid synthesis of silver nanoparticles using culture supernatants of Enterobacteria: a novel biological approach. Process Biochem. 2007; 42(5):919-923.

171. Raveendran P, Fu J, Wallen SL. Completely "green" synthesis and stabilization of metal nanoparticles. J Am Chem Soc. 2003;125(46): 13940-13941.

172. Vigneshwaran N, Nachane RP, Balasubramanya RH, Varadarajan PV. A novel one-pot 'green'synthesis of stable silver nanoparticles using soluble starch. Carbohydr Res. 2006;341(12):2012-2018.

173. Tai CY, Wang YH, Liu HS. A green process for preparing silver nanoparticles using spinning disk reactor. AIChE J. 2008;54(2):445-452.

174. Gao X, Wei L, Yan H, Xu B. Green synthesis and characteristic of core-shell structure silver/starch nanoparticles. Mater Lett. 2011; 65(19-20):2963-2965.

175. El-Sheikh MA. A novel photosynthesis of carboxymethyl starchstabilized silver nanoparticles. Sci World J. 2014;2014:514563.

176. El-Rafie M, Ahmed HB, Zahran M. Facile precursor for synthesis of silver nanoparticles using alkali treated maize starch. Int Sch Res Notices. 2014;2014:702396.

177. Liu Y, Chen S, Zhong L, Wu G. Preparation of high-stable silver nanoparticle dispersion by using sodium alginate as a stabilizer under gamma radiation. Radiat Phys Chem. 2009;78(4):251-255.

178. Saha S, Pal A, Kundu S, Basu S, Pal T. Photochemical green synthesis of calcium-alginate-stabilized Ag and Au nanoparticles and their catalytic application to 4-nitrophenol reduction. Langmuir. 2009;26(4): 2885-2893.

179. Zahran MK, Ahmed HB, El-Rafie MH. Alginate mediate for synthesis controllable sized AgNPs. Carbohydr Polym. 2014;111:10-17.

180. Kora AJ, Beedu SR, Jayaraman A. Size-controlled green synthesis of silver nanoparticles mediated by gum ghatti (Anogeissus latifolia) and its biological activity. Org Med Chem Lett. 2012;2(1):17.

181. Rastogi L, Kora AJ, Sashidhar R. Antibacterial effects of gum kondagogu reduced/stabilized silver nanoparticles in combination with various antibiotics: a mechanistic approach. Appl Nanosci. 2015;5(5): 535-543.

182. Emam HE, El-Rafie M, Ahmed HB, Zahran M. Room temperature synthesis of metallic nanosilver using acacia to impart durable biocidal effect on cotton fabrics. Fibers Polym. 2015;16(8):1676-1687.

183. Emam HE, Zahran MK. $\operatorname{Ag}(0)$ nanoparticles containing cotton fabric: synthesis, characterization, color data and antibacterial action. Int $J$ Biol Macromol. 2015;75:106-114.

184. Abdel-Mohsen A, Abdel-Rahman RM, Fouda MM, et al. Preparation, characterization and cytotoxicity of schizophyllan/silver nanoparticle composite. Carbohydr Polym. 2014;102:238-245.

185. Kemp MM, Kumar A, Clement D, Ajayan P, Mousa S, Linhardt RJ. Hyaluronan- and heparin-reduced silver nanoparticles with antimicrobial properties. Nanomedicine (Lond). 2009;4(4):421-429.

186. Laudenslager MJ, Schiffman JD, Schauer CL. Carboxymethyl chitosan as a matrix material for platinum, gold, and silver nanoparticles. Biomacromolecules. 2008;9(10):2682-2685.

187. Ishihara M, Nguyen VQ, Mori Y, Nakamura S, Hattori H. Adsorption of silver nanoparticles onto different surface structures of chitin/ chitosan and correlations with antimicrobial activities. Int J Mol Sci. 2015;16(6):13973-13988.
188. Kibeche A, Dionne A, Brion-Roby R, Gagnon C, Gagnon J. Simple and green technique for sequestration and concentration of silver nanoparticles by polysaccharides immobilized on glass beads in aqueous media. Chem Cent J. 2015;9(1):34.

189. Wei D, Qian W, Wu D, Xia Y, Liu X. Synthesis, properties, and surface enhanced Raman scattering of gold and silver nanoparticles in chitosan matrix. J Nanosci Nanotechnol. 2009;9(4):2566-2573.

190. Thomas V, Yallapu MM, Sreedhar B, Bajpai SK. Fabrication, characterization of chitosan/nanosilver film and its potential antibacterial application. J Biomater Sci Polym Ed. 2009;20(14):2129-2144.

191. Tummalapalli M, Deopura BL, Alam MS, Gupta B. Facile and green synthesis of silver nanoparticles using oxidized pectin. Mater Sci Eng C Mater Biol Appl. 2015;50:31-36.

192. Abdel-Halim E, Al-Deyab SS. Utilization of hydroxypropyl cellulose for green and efficient synthesis of silver nanoparticles. Carbohydr Polym. 2011;86(4):1615-1622.

193. Hussain MA, Shah A, Jantan I, et al. Hydroxypropylcellulose as a novel green reservoir for the synthesis, stabilization, and storage of silver nanoparticles. Int J Nanomedicine. 2015;10:2079-2088.

194. Rehan M, Mashaly HM, Mowafi S, El-Kheir AA, Emam HE. Multifunctional textile design using in-situ AgNPs incorporation into natural fabric matrix. Dyes Pigm. 2015;118:9-17.

195. He H, Tao G, Wang Y, et al. In situ green synthesis and characterization of sericin-silver nanoparticle composite with effective antibacterial activity and good biocompatibility. Mater Sci Eng C. 2017;80: 509-516.

196. Tao G, Cai R, Wang Y, et al. Biosynthesis and characterization of AgNPs-Silk/PVA film for potential packaging application. Materials (Basel). 2017;10(6):pii:E667.

197. Wang Y, Kim UJ, Blasioli DJ, Kim HJ, Kaplan DL. In vitro cartilage tissue engineering with $3 \mathrm{D}$ porous aqueous-derived silk scaffolds and mesenchymal stem cells. Biomaterials. 2005;26(34):7082-7094.

198. Wang Y, Kim HJ, Vunjak-Novakovic G, Kaplan DL. Stem cellbased tissue engineering with silk biomaterials. Biomaterials. 2006; 27(36):6064-6082.

199. Vepari C, Kaplan DL. Silk as a biomaterial. Prog Polym Sci. 2007; 32(8-9):991-1007.

200. Fei X, Shao Z, Chen X. Synthesis of hierarchical three-dimensional copper oxide nanostructures through a biomineralization-inspired approach. Nanoscale. 2013;5(17):7991-7997.

201. Mi R, Liu Y, Chen X, Shao Z. Structure and properties of various hybrids fabricated by silk nanofibrils and nanohydroxyapatite. Nanoscale. 2016;8(48):20096-20102.

202. Selvakannan PR, Swami A, Srisathiyanarayanan D, et al. Synthesis of aqueous $\mathrm{Au}$ core- $\mathrm{Ag}$ shell nanoparticles using tyrosine as a $\mathrm{pH}-$ dependent reducing agent and assembling phase-transferred silver nanoparticles at the air-water interface. Langmuir. 2004;20(18): 7825-7836.

203. Liu B, Xu H, Zhao H, Liu W, Zhao L, Li Y. Preparation and characterization of intelligent starch/PVA films for simultaneous colorimetric indication and antimicrobial activity for food packaging applications. Carbohydr Polym. 2017;157:842-849.

204. Chiellini E, Cinelli P, Chiellini F, Imam SH. Environmentally degradable bio-based polymeric blends and composites. Macromol Biosci. 2004;4(3):218-231.

205. Dailey LA, Wittmar M, Kissel T. The role of branched polyesters and their modifications in the development of modern drug delivery vehicles. J Control Release. 2005;101(1-3):137-149.

206. Cano A, Fortunati E, Cháfer M, González-Martínez C, Chiralt A, Kenny J. Effect of cellulose nanocrystals on the properties of pea starch-poly (vinyl alcohol) blend films. J Mater Sci. 2015;50(21):6979-6992.

207. Geimi AK, Novoselov KS. The rise of graphene. Nat Mater. 2007; 6(3):183-191.

208. Tang XZ, Cao Z, Zhang H-B, Liu J, Yu ZZ. Growth of silver nanocrystals on graphene by simultaneous reduction of graphene oxide and silver ions with a rapid and efficient one-step approach. Chem Commun(Camb). 2011;47(11):3084-3086. 
209. Georgakilas V, Gournis D, Tzitzios V, Pasquato L, Guldi DM, Prato M. Decorating carbon nanotubes with metal or semiconductor nanoparticles. J Mater Chem. 2007;17(26):2679-2694.

210. Williams G, Seger B, Kamat PV. TiO2-graphene nanocomposites. UV-assisted photocatalytic reduction of graphene oxide. ACS Nano. 2008;2(7):1487-1491.

211. Ocsoy I, Gulbakan B, Chen T, et al. DNA-guided metal-nanoparticle formation on graphene oxide surface. Adv Mater. 2013;25(16): 2319-2325.

212. Ocsoy I, Paret ML, Ocsoy MA, et al. Nanotechnology in plant disease management: DNA-directed silver nanoparticles on graphene oxide as an antibacterial against Xanthomonas perforans. ACS Nano. 2013; 7(10):8972-8980.

213. Strayer A, Ocsoy I, Tan W, Jones JB, Paret ML. Low concentrations of a silver-based nanocomposite to manage bacterial spot of tomato in the greenhouse. Plant Dis. 2016;100(7):1460-1465.

214. Liu L, Liu J, Wang Y, Yan X, Sun DD. Facile synthesis of monodispersed silver nanoparticles on graphene oxide sheets with enhanced antibacterial activity. New J Chem. 2011;35(7):1418-1423.

215. Xu WP, Zhang LC, Li JP, et al. Facile synthesis of silver@graphene oxide nanocomposites and their enhanced antibacterial properties. J Mater Chem. 2011;21(12):4593-4597.

216. Bao Q, Zhang D, Qi P. Synthesis and characterization of silver nanoparticle and grapheme oxide nanosheet composites as a bactericidal agent for water disinfection. J Colloid Interface Sci. 2011;360(2): 463-470.

217. Ocsoy I, Temiz M, Celik C, Altinsoy B, Yilmaz V, Duman F. A green approach for formation of silver nanoparticles on magnetic graphene oxide and highly effective antimicrobial activity and reusability. J Mol Liq. 2017;227(Suppl C):147-152.

218. Sondi I, Salopek-Sondi B. Silver nanoparticles as antimicrobial agent: a case study on E. coli as a model for Gram-negative bacteria. J Colloid Interface Sci. 2004;275(1):177-182.

219. Devi LS, Joshi SR. Antimicrobial and synergistic effects of silver nanoparticles synthesized using soil fungi of high altitudes of Eastern Himalaya. Mycobiology. 2012;40(1):27-34.

220. Bonde S, Rathod D, Ingle A, Ade R, Gade A, Rai M. Murraya koenigiimediated synthesis of silver nanoparticles and its activity against three human pathogenic bacteria. Nanosci Methods. 2012;1(1):25-36.

221. Liu HL, Dai SA, Fu KY, Hsu SH. Antibacterial properties of silver nanoparticles in three different sizes and their nanocomposites with a new waterborne polyurethane. Int J Nanomedicine. 2010;5: 1017-1028.

222. Shameli K, Ahmad MB, Jazayeri SD, et al. Investigation of antibacterial properties silver nanoparticles prepared via green method. Chem Cent J. 2012;6(1):73.

223. Gade A, Gaikwad S, Tiwari V, Yadav A, Ingle A, Rai M. Biofabrication of silver nanoparticles by Opuntia ficus-indica: in vitro antibacterial activity and study of the mechanism involved in the synthesis. Curr Nanosci. 2010;6(4):370-375.

224. Bin Ahmad M, Lim JJ, Shameli K, Ibrahim NA, Tay MY, Chieng BW. Antibacterial activity of silver bionanocomposites synthesized by chemical reduction route. Chem Cent J. 2012;6(1):101.

225. Rajkuberan C, Sudha K, Sathishkumar G, Sivaramakrishnan S. Antibacterial and cytotoxic potential of silver nanoparticles synthesized using latex of Calotropis gigantea L. Spectrochim Acta A Mol Biomol Spectrosc. 2015;136(Pt B):924-930.

226. Ramar M, Manikandan B, Marimuthu PN, et al. Synthesis of silver nanoparticles using Solanum trilobatum fruits extract and its antibacterial, cytotoxic activity against human breast cancer cell line MCF 7. Spectrochim Acta A Mol Biomol Spectrosc. 2015;140:223-228.

227. Kvitek L, Panáčk A, Soukupova J, et al. Effect of surfactants and polymers on stability and antibacterial activity of silver nanoparticles (NPs). J Phys Chem C. 2008;112(15):5825-5834.

228. Kim SH, Lee HS, Ryu D-S, Choi SJ, Lee DS. Antibacterial activity of silver-nanoparticles against Staphylococcus aureus and Escherichia coli. Korean J Microbiol Biotechnol. 2011;39(1):77-85.
229. Shameli K, Ahmad MB, Zargar M, Yunus WM, Rustaiyan A, Ibrahim NA. Synthesis of silver nanoparticles in montmorillonite and their antibacterial behavior. Int J Nanomedicine. 2011;6:581-590.

230. Marslin G, Selvakesavan RK, Franklin G, Sarmento B, Dias AC. Antimicrobial activity of cream incorporated with silver nanoparticles biosynthesized from Withania somnifera. Int J Nanomedicine. 2015;10:5955-5963.

231. Salem W, Haridy M, Sayed W, Hassan N. Antibacterial activity of silver nanoparticles synthesized from latex and leaf extract of Ficus sycomorus. Ind Crops Prod. 2014;62:228-234.

232. Ajitha B, Ashok Kumar Reddy Y, Shameer S, Rajesh K, Suneetha Y, Sreedhara Reddy P. Lantana camara leaf extract mediated silver nanoparticles: antibacterial, green catalyst. J Photochem Photobiol B. 2015; 149:84-92.

233. Ahmed KB, Senthilnathan R, Megarajan S, Anbazhagan V. Sunlight mediated synthesis of silver nanoparticles using redox phytoprotein and their application in catalysis and colorimetric mercury sensing. J Photochem Photobiol B. 2015;151:39-45.

234. Kim JS, Kuk E, Yu KN, et al. Antimicrobial effects of silver nanoparticles. Nanomedicine. 2007;3(1):95-101.

235. Raffi M, Hussain F, Bhatti T, Akhter J, Hameed A, Hasan M. Antibacterial characterization of silver nanoparticles against $E$. coli ATCC15224. J Mater Sci Technol. 2008;24(2):192-196.

236. Nadworny PL, Wang J, Tredget EE, Burrell RE. Anti-inflammatory activity of nanocrystalline silver in a porcine contact dermatitis model. Nanomedicine. 2008;4(3):241-251.

237. Sibbald RG, Contreras-Ruiz J, Coutts P, Fierheller M, Rothman A, Woo K. Bacteriology, inflammation, and healing: a study of nanocrystalline silver dressings in chronic venous leg ulcers. Adv Skin Wound Care. 2007;20(10):549-558.

238. Tian J, Wong KK, Ho CM, et al. Topical delivery of silver nanoparticles promotes wound healing. ChemMedChem. 2007;2(1):129-136.

239. Wright JB, Lam K, Buret AG, Olson ME, Burrell RE. Early healing events in a porcine model of contaminated wounds: effects of nanocrystalline silver on matrix metalloproteinases, cell apoptosis, and healing. Wound Repair Regen. 2002;10(3):141-151.

240. Huang Y, Li X, Liao Z, et al. A randomized comparative trial between Acticoat and SD-Ag in the treatment of residual burn wounds, including safety analysis. Burns. 2007;33(2):161-166.

241. Atiyeh BS, Costagliola M, Hayek SN, Dibo SA. Effect of silver on burn wound infection control and healing: review of the literature. Burns. 2007;33(2):139-148.

242. Sládková M, Vlčková B, Pavel I, Šišková K, Šlouf M. Surfaceenhanced Raman scattering from a single molecularly bridged silver nanoparticle aggregate. J Mol Struct. 2009;924-926:567-570.

243. Choi O, Deng KK, Kim NJ, Ross L Jr, Surampalli RY, Hu Z. The inhibitory effects of silver nanoparticles, silver ions, and silver chloride colloids on microbial growth. Water Res. 2008;42(12):3066-3074.

244. Foldbjerg R, Olesen P, Hougaard M, Dang DA, Hoffmann HJ, Autrup H. PVP-coated silver nanoparticles and silver ions induce reactive oxygen species, apoptosis and necrosis in THP-1 monocytes. Toxicol Lett. 2009;190(2):156-162.

245. Chen J, Han C, Lin X, Tang Z, Su S. [Effect of silver nanoparticle dressing on second degree burn wound]. Zhonghua Wai Ke Za Zhi. 2006;44(1):50-52. Chinese [with English abstract].

246. Vlachou E, Chipp E, Shale E, Wilson YT, Papini R, Moiemen NS. The safety of nanocrystalline silver dressings on burns: a study of systemic silver absorption. Burns. 2007;33(8):979-985.

247. Asz J, Asz D, Moushey R, Seigel J, Mallory SB, Foglia RP. Treatment of toxic epidermal necrolysis in a pediatric patient with a nanocrystalline silver dressing. J Pediatr Surg. 2006;41(12):e9-e12.

248. Yang JY, Huang CY, Chuang SS, Chen CC. A clinical experience of treating exfoliative wounds using nanocrystalline silver-containing dressings (Acticoat). Burns. 2007;33(6):793-797.

249. Kim KJ, Sung WS, Moon SK, Choi JS, Kim JG, Lee DG. Antifungal effect of silver nanoparticles on dermatophytes. JMicrobiol Biotechnol. 2008;18(8):1482-1484. 
250. Velluti F, Mosconi N, Acevedo A, et al. Synthesis, characterization, microbiological evaluation, genotoxicity and synergism tests of new nano silver complexes with sulfamoxole: X-ray diffraction of [Ag2 (SMX) 2]·DMSO. J Inorg Biochem. 2014;141:58-69.

251. Gajbhiye M, Kesharwani J, Ingle A, Gade A, Rai M. Fungus-mediated synthesis of silver nanoparticles and their activity against pathogenic fungi in combination with fluconazole. Nanomedicine. 2009; 5(4):382-386.

252. Jo YK, Kim BH, Jung G. Antifungal activity of silver ions and nanoparticles on phytopathogenic fungi. Plant Dis. 2009;93(10):1037-1043.

253. Ogar A, Tylko G, Turnau K. Antifungal properties of silver nanoparticles against indoor mould growth. Sci Total Environ. 2015;521-522: 305-314.

254. Nasrollahi A, Pourshamsian K, Mansourkiaee P. Antifungal activity of silver nanoparticles on some of fungi. Int J Nanodimens. 2011;1(3) 233-239.

255. Savithramma N, Rao ML, Rukmini K, Devi PS. Antimicrobial activity of silver nanoparticles synthesized by using medicinal plants. Int $J$ Chemtech Res. 2011;3(3):1394-1402.

256. Kaur P, Thakur R, Choudhary A. An in vitro study of the antifungal activity of silver/chitosan nanoformulations against important seed borne pathogens. Int J Sci Technol Res. 2012;1:83-86.

257. Arjun TV, Bholay A. Biosynthesis of silver nanoparticles and its antifungal activities. J Environ Res Dev. 2012;7(1A):338-345.

258. Xu Y, Gao C, Li X, et al. In vitro antifungal activity of silver nanoparticles against ocular pathogenic filamentous fungi. J Ocul Pharmacol Ther. 2013;29(2):270-274.

259. Balakumaran MD, Ramachandran R, Kalaichelvan PT. Exploitation of endophytic fungus, Guignardia mangiferae for extracellular synthesis of silver nanoparticles and their in vitro biological activities. Microbiol Res. 2015;178:9-17.

260. Kathiravan V, Ravi S, Ashokkumar S, Velmurugan S, Elumalai K, Khatiwada CP. Green synthesis of silver nanoparticles using Croton sparsiflorus morong leaf extract and their antibacterial and antifungal activities. Spectrochim Acta A Mol Biomol Spectrosc. 2015;139:200-205.

261. Mallmann EJ, Cunha FA, Castro BN, Maciel AM, Menezes EA, Fechine PB. Antifungal activity of silver nanoparticles obtained by green synthesis. Rev Inst Med Trop Sao Paulo. 2015;57(2):165-167.

262. Anasane N, Golińska P, Wypij M, Rathod D, Dahm H, Rai M. Acidophilic actinobacteria synthesised silver nanoparticles showed remarkable activity against fungi-causing superficial mycoses in humans. Mycoses. 2016;59(3):157-166.

263. Artunduaga Bonilla JJ, Paredes Guerrero DJ, Sánchez Suárez CI, Ortiz López CC, Torres Sáez RG. In vitro antifungal activity of silver nanoparticles against fluconazole-resistant Candida species. World $J$ Microbiol Biotechnol. 2015;31(11):1801-1809.

264. Devi LS, Joshi SR. Evaluation of the antimicrobial potency of silver nanoparticles biosynthesized by using an endophytic fungus, Cryptosporiopsis ericae PS4. J Microbiol. 2014;52(8):667-674.

265. Khatami M, Pourseyedi S. Phoenix dactylifera (date palm) pit aqueous extract mediated novel route for synthesis high stable silver nanoparticles with high antifungal and antibacterial activity. IET Nanobiotechnol. 2015;9(4):184-190.

266. Vazquez-Muñoz R, Avalos-Borja M, Castro-Longoria E. Ultrastructural analysis of Candida albicans when exposed to silver nanoparticles. PLoS One. 2014;9(10):e108876.

267. Naz SS, Shah MR, Islam NU, et al. Synthesis and bioactivities of silver nanoparticles capped with 5-amino- $\beta$-resorcylic acid hydrochloride dihydrate. J Nanobiotechnology. 2014;12(1):34.

268. Prabhu D, Arulvasu C, Babu G, Manikandan R, Srinivasan P. Biologically synthesized green silver nanoparticles from leaf extract of Vitex negundo L. induce growth-inhibitory effect on human colon cancer cell line HCT15. Process Biochem. 2013;48(2):317-324.

269. Jeyaraj M, Rajesh M, Arun R, et al. An investigation on the cytotoxicity and caspase-mediated apoptotic effect of biologically synthesized silver nanoparticles using Podophyllum hexandrum on human cervical carcinoma cells. Colloids Surf B Biointerfaces. 2013;102:708-717.
270. Jeyaraj M, Sathishkumar G, Sivanandhan G, et al. Biogenic silver nanoparticles for cancer treatment: an experimental report. Colloids Surf B Biointerfaces. 2013;106:86-92.

271. Satyavani K, Gurudeeban S, Ramanathan T, Balasubramanian T. Toxicity study of silver nanoparticles synthesized from Suaeda monoica on Hep-2 cell line. Avicenna J Med Biotechnol. 2012;4(1):35-39.

272. Piao MJ, Kang KA, Lee IK, et al. Silver nanoparticles induce oxidative cell damage in human liver cells through inhibition of reduced glutathione and induction of mitochondria-involved apoptosis. Toxicol Lett. 2011;201(1):92-100.

273. Jacob SJ, Finub JS, Narayanan A. Synthesis of silver nanoparticles using Piper longum leaf extracts and its cytotoxic activity against Hep-2 cell line. Colloids Surf B Biointerfaces. 2012;91:212-214.

274. Durán N, Marcato PD, Conti RD, Alves OL, Costa F, Brocchi M. Potential use of silver nanoparticles on pathogenic bacteria, their toxicity and possible mechanisms of action. J Braz Chem Soc. 2010; 21(6):949-959.

275. Liu J, Zhao Y, Guo Q, et al. TAT-modified nanosilver for combating multidrug-resistant cancer. Biomaterials. 2012;33(26):6155-6161.

276. He Y, Du Z, Ma S, et al. Biosynthesis, antibacterial activity and anticancer effects against prostate cancer (PC-3) cells of silver nanoparticles using Dimocarpus Longan Lour. Nanoscale Res Lett. 2016; 11(1):300.

277. Lokina S, Stephen A, Kaviyarasan V, Arulvasu C, Narayanan V. Cytotoxicity and antimicrobial activities of green synthesized silver nanoparticles. Eur J Med Chem. 2014;76:256-263.

278. Sankar R, Karthik A, Prabu A, Karthik S, Shivashangari KS, Ravikumar V. Origanum vulgare mediated biosynthesis of silver nanoparticles for its antibacterial and anticancer activity. Colloids Surf B Biointerfaces. 2013;108:80-84.

279. Vasanth K, Ilango K, MohanKumar R, Agrawal A, Dubey GP. Anticancer activity of Moringa oleifera mediated silver nanoparticles on human cervical carcinoma cells by apoptosis induction. Colloids Surf B Biointerfaces. 2014;117:354-359.

280. Dwivedi S, Saquib Q, Al-Khedhairy AA, Ahmad J, Siddiqui MA, Musarrat J. Rhamnolipids functionalized AgNPs-induced oxidative stress and modulation of toxicity pathway genes in cultured MCF-7 cells. Colloids Surf B Biointerfaces. 2015;132:290-298.

281. Guo D, Dou D, Ge L, Huang Z, Wang L, Gu N. A caffeic acid mediated facile synthesis of silver nanoparticles with powerful anti-cancer activity. Colloids Surf B Biointerfaces. 2015;134:229-234.

282. Rajasekharreddy P, Rani PU. Biofabrication of Ag nanoparticles using Sterculia foetida $\mathrm{L}$. seed extract and their toxic potential against mosquito vectors and HeLa cancer cells. Mater Sci Eng C Mater Biol Appl. 2014;39:203-212.

283. Mata R, Nakkala JR, Sadras SR. Catalytic and biological activities of green silver nanoparticles synthesized from Plumeria alba (frangipani) flower extract. Mater Sci Eng C Mater Biol Appl. 2015;51:216-225.

284. Kaplan A, Akalin Ciftci G, Kutlu HM. Cytotoxic, anti-proliferative and apoptotic effects of silver nitrate against H-ras transformed 5RP7. Cytotechnology. 2016;68(5):1727-1735.

285. Pandurangan M, Enkhtaivan G, Venkitasamy B, et al. Time and concentration-dependent therapeutic potential of silver nanoparticles in cervical carcinoma cells. Biol Trace Elem Res. 2016;170(2): 309-319.

286. El Kassas HY, Attia AA. Bactericidal application and cytotoxic activity of biosynthesized silver nanoparticles with an extract of the red seaweed Pterocladiella capillacea on the HepG2 cell line. Asian Pac J Cancer Prev. 2014;15(3):1299-1306.

287. Ramalingam V, Rajaram R, PremKumar C, et al. Biosynthesis of silver nanoparticles from deep sea bacterium Pseudomonas aeruginosa JQ989348 for antimicrobial, antibiofilm, and cytotoxic activity. J Basic Microbiol. 2014;54(9):928-936.

288. Manivasagan P, Venkatesan J, Senthilkumar K, Sivakumar K, Kim SK. Biosynthesis, antimicrobial and cytotoxic effect of silver nanoparticles using a novel Nocardiopsis sp. MBRC-1. Biomed Res Int. 2013; 2013:287638. 
289. Duraipandy N, Lakra R, Kunnavakkam Vinjimur S, Samanta D, K PS, Kiran MS. Caging of plumbagin on silver nanoparticles imparts selectivity and sensitivity to plumbagin for targeted cancer cell apoptosis. Metallomics. 2014;6(11):2025-2033.

290. Yeasmin S, Datta HK, Chaudhuri S, Malik D, Bandyopadhyay A. In-vitro anti-cancer activity of shape controlled silver nanoparticles (AgNPs) in various organ specific cell lines. J Mol Liq. 2017;242: 757-766.

291. Venil CK, Sathishkumar P, Malathi M, et al. Synthesis of flexirubinmediated silver nanoparticles using Chryseobacterium artocarpi CECT 8497 and investigation of its anticancer activity. Mater Sci Eng C Mater Biol Appl. 2016;59:228-234.

292. Venkatesan J, Lee JY, Kang DS, et al. Antimicrobial and anticancer activities of porous chitosan-alginate biosynthesized silver nanoparticles. Int J Biol Macromol. 2017;98:515-525.

293. Salahuddin N, Elbarbary AA, Alkabes HA. Antibacterial and anticancer activity of loaded quinazolinone polypyrrole/chitosan silver chloride nanocomposite. Int J Polym Mater. 2017;66(6):307-316.

294. El-Sherbiny IM, Salih E, Yassin AM, Hafez EE. Newly developed chitosan-silver hybrid nanoparticles: biosafety and apoptosis induction in HepG2 cells. J Nanopart Res. 2016;18(7):172.

295. Narasimha G. Antiviral activity of silver nanoparticles synthesized by fungal strain Aspergillus niger. J Nanosci Nanotechnol. 2012; 6(1):18-20.

296. Speshock JL, Murdock RC, Braydich-Stolle LK, Schrand AM, Hussain SM. Interaction of silver nanoparticles with Tacaribe virus. J Nanobiotechnology. 2010;8(1):19.

297. Gaikwad S, Ingle A, Gade A, et al. Antiviral activity of mycosynthesized silver nanoparticles against herpes simplex virus and human parainfluenza virus type 3. Int J Nanomedicine. 2013;8:4303-4314.

298. Baram-Pinto D, Shukla S, Perkas N, Gedanken A, Sarid R. Inhibition of herpes simplex virus type 1 infection by silver nanoparticles capped with mercaptoethane sulfonate. Bioconjug Chem. 2009;20(8): $1497-1502$.

299. Lara HH, Ayala-Nuñez NV, Ixtepan-Turrent L, Rodriguez-Padilla C. Mode of antiviral action of silver nanoparticles against HIV-1. J Nanobiotechnology. 2010;8(1):1.

300. Morrill K, May K, Leek D, et al. Spectrum of antimicrobial activity associated with ionic colloidal silver. J Altern Complement Med. 2013; 19(3):224-231.

301. Orlowski P, Tomaszewska E, Gniadek M, et al. Tannic acid modified silver nanoparticles show antiviral activity in herpes simplex virus type 2 infection. PLoS One. 2014;9(8):e104113.

302. Nadhman A, Nazir S, Khan MI, et al. PEGylated silver doped zinc oxide nanoparticles as novel photosensitizers for photodynamic therapy against Leishmania. Free Radic Biol Med. 2014;77:230-238.

303. Marr AK, McGwire BS, McMaster WR. Modes of action of Leishmanicidal antimicrobial peptides. Future Microbiol. 2012;7(9):1047-1059.

304. Rossi-Bergmann B, Pacienza-Lima W, Marcato PD, de Conti R, Durán N. Therapeutic potential of biogenic silver nanoparticles in murine cutaneous leishmaniasis. J Nano Res. 2012;20:89-97.

305. Kamareddine $\mathrm{L}$. The biological control of the malaria vector. Toxins (Basel). 2012;4(9):748-767.

306. Ji Z, Shen X, Yue X, et al. Facile synthesis of magnetically separable reduced graphene oxide/magnetite/silver nanocomposites with enhanced catalytic activity. J Colloid Interface Sci. 2015;459:79-85.

307. Jiang Z, Jiang D, Showkot Hossain AM, Qian K, Xie J. In situ synthesis of silver supported nanoporous iron oxide microbox hybrids from metalorganic frameworks and their catalytic application in p-nitrophenol reduction. Phys Chem Chem Phys. 2015;17(4):2550-2559.

308. Sharma NC, Sahi SV, Nath S, Parsons JG, Gardea-Torresdey JL, Pal T. Synthesis of plant-mediated gold nanoparticles and catalytic role of biomatrix-embedded nanomaterials. Environ Sci Technol. 2007; 41(14):5137-5142.

309. Saxena A, Tripathi RM, Zafar F, Singh P. Green synthesis of silver nanoparticles using aqueous solution of Ficus benghalensis leaf extract and characterization of their antibacterial activity. Mater Lett. 2012;67(1):91-94.
310. Shankar SS, Rai A, Ahmad A, Sastry M. Rapid synthesis of Au, Ag, and bimetallic $\mathrm{Au}$ core- $\mathrm{Ag}$ shell nanoparticles using Neem (Azadirachta indica) leaf broth. J Colloid Interface Sci. 2004;275(2):496-502.

311. Tripathi RM, Ranac D, Shrivastav A, Singh RP, Shrivastav BR. Biogenic synthesis of silver nanoparticles using Saraca indica leaf extract and evaluation of their antibacterial activity. Nano Biomed Eng. 2013;5(1):50-56.

312. Shrivastava S, Bera T, Roy A, Singh G, Ramachandrarao P, Dash D. Characterization of enhanced antibacterial effects of novel silver nanoparticles. Nanotechnology. 2007;18(22):225103.

313. Li WR, Xie XB, Shi QS, Zeng HY, Ou-Yang YS, Chen YB. Antibacterial activity and mechanism of silver nanoparticles on Escherichia coli. Appl Microbiol Biotechnol. 2010;85(4):1115-1122.

314. Masip L, Veeravalli K, Georgiou G. The many faces of glutathione in bacteria. Antioxid Redox Signal. 2006;8(5-6):753-762.

315. Zhang D, Zhao YX, Gao YJ, et al. Anti-bacterial and in vivo tumor treatment by reactive oxygen species generated by magnetic nanoparticles. J Mater Chem B. 2013;1(38):5100-5107.

316. Minai L, Yeheskely-Hayon D, Yelin D. High levels of reactive oxygen species in gold nanoparticle-targeted cancer cells following femtosecond pulse irradiation. Sci Rep. 2013;3:2146.

317. Franco-Molina MA, Mendoza-Gamboa E, Sierra-Rivera CA, et al. Antitumor activity of colloidal silver on MCF-7 human breast cancer cells. J Exp Clin Cancer Res. 2010;29(1):148.

318. Ueda S, Masutani H, Nakamura H, Tanaka T, Ueno M, Yodoi J. Redox control of cell death. Antioxid Redox Signal. 2002;4(3):405-414.

319. Garrido C, Galluzzi L, Brunet M, Puig P, Didelot C, Kroemer G. Mechanisms of cytochrome c release from mitochondria. Cell Death Differ. 2006;13(9):1423-1433.

320. Marambio-Jones C, Hoek EM. A review of the antibacterial effects of silver nanomaterials and potential implications for human health and the environment. J Nanopart Res. 2010;12(5):1531-1551.

321. Tannock IF, Rotin D. Acid $\mathrm{pH}$ in tumors and its potential for therapeutic exploitation. Cancer Res. 1989;49(16):4373-4384.

322. Asharani PV, Lian Wu Y, Gong Z, Valiyaveettil S. Toxicity of silver nanoparticles in zebrafish models. Nanotechnology. 2008;19(25): 255102.

323. Hsin YH, Chen CF, Huang S, Shih TS, Lai PS, Chueh PJ. The apoptotic effect of nanosilver is mediated by a ROS- and JNK-dependent mechanism involving the mitochondrial pathway in NIH3T3 cells. Toxicol Lett. 2008;179(3):130-139.

324. AshaRani PV, Low Kah Mun G, Hande MP, Valiyaveettil S. Cytotoxicity and genotoxicity of silver nanoparticles in human cells. ACS Nano. 2009;3(2):279-290.

325. Netchareonsirisuk P, Puthong S, Dubas S, Palaga T, Komolpis K. Effect of capping agents on the cytotoxicity of silver nanoparticles in human normal and cancer skin cell lines. J Nanopart Res. 2016; 18(11):322.

326. Boudreau MD, Imam MS, Paredes AM, et al. Differential effects of silver nanoparticles and silver ions on tissue accumulation, distribution, and toxicity in the Sprague Dawley rat following daily oral gavage administration for 13 weeks. Toxicol Sci. 2016;150(1): 131-160.

327. Kim MJ, Shin S. Toxic effects of silver nanoparticles and nanowires on erythrocyte rheology. Food Chem Toxicol. 2014;67:80-86.

328. Haase A, Tentschert J, Jungnickel H, et al. Toxicity of silver nanoparticles in human macrophages: uptake, intracellular distribution and cellular responses. J Phys Conf Ser. 2011;304(1):012030.

329. Pratsinis A, Hervella P, Leroux JC, Pratsinis SE, Sotiriou GA. Toxicity of silver nanoparticles in macrophages. Small. 2013;9(15): 2576-2584.

330. Faedmaleki F, H Shirazi F, Salarian AA, Ahmadi Ashtiani H, Rastegar $\mathrm{H}$. Toxicity effect of silver nanoparticles on mice liver primary cell culture and HepG(2) cell line. Iran J Pharm Res. 2014;13(1): 235-242.

331. Samberg ME, Oldenburg SJ, Monteiro-Riviere NA. Evaluation of silver nanoparticle toxicity in skin in vivo and keratinocytes in vitro. Environ Health Perspect. 2010;118(3):407-413. 
332. Gliga AR, Skoglund S, Wallinder IO, Fadeel B, Karlsson HL. Sizedependent cytotoxicity of silver nanoparticles in human lung cells: the role of cellular uptake, agglomeration and Ag release. Part Fibre Toxicol. 2014;11:11.

333. Huang CL, Hsiao IL, Lin HC, Wang CF, Huang YJ, Chuang CY. Silver nanoparticles affect on gene expression of inflammatory and neurodegenerative responses in mouse brain neural cells. Environ Res. 2015;136:253-263.

334. Zhang XF, Liu ZG, Shen W, Gurunathan S. Silver nanoparticles: synthesis, characterization, properties, applications, and therapeutic approaches. Int J Mol Sci. 2016;17(9):pii:E1534.

335. Gurunathan S. Rapid biological synthesis of silver nanoparticles and their enhanced antibacterial effects against Escherichia fergusonii and Streptococcus mutans. Arab J Chem. Epub 2014 Nov 20.

336. Sun L, Singh AK, Vig K, Pillai SR, Singh SR. Silver nanoparticles inhibit replication of respiratory syncytial virus. J Biomed Nanotechnol. 2008;4(2):149-158.

337. Murray HW. Susceptibility of Leishmania to oxygen intermediates and killing by normal macrophages. $J$ Exp Med. 1981;153(5):1302-1315.

338. Saifuddin N, Wong CW, Yasumira AA. Rapid biosynthesis of silver nanoparticles using culture supernatant of bacteria with microwave irradiation. J Chem. 2009;6(1):61-70.

339. Schröfel A, Kratošová G, Šafařík I, Šafaříková M, Raška I, Shor LM. Applications of biosynthesized metallic nanoparticles-a review. Acta Biomater. 2014;10(10):4023-4042.

340. Majdalawieh A, Kanan MC, El-Kadri O, Kanan SM. Recent advances in gold and silver nanoparticles: synthesis and applications. J Nanosci Nanotechnol. 2014;14(7):4757-4780.

341. Emam HE, Ahmed HB. Polysaccharides templates for assembly of nanosilver. Carbohydr Polym. 2016;135:300-307.

342. Lansdown A. Silver in health care: antimicrobial effects and safety in use. In: Hipler UC, Elsner P, editors. Biofunctional Textiles and the Skin. Vol 33. Basel: Karger Publishers; 2006:17-34.

343. Conrad AH, Tramp CR, Long CJ, Wells DC, Paulsen AQ, Conrad GW. Ag+ alters cell growth, neurite extension, cardiomyocyte beating, and fertilized egg constriction. Aviat Space Environ Med. 1999;70(11):1096-1105.

344. Lemire JA, Harrison JJ, Turner RJ. Antimicrobial activity of metals: mechanisms, molecular targets and applications. Nat Rev Microbiol. 2013;11(6):371-384.

345. Kim YS, Kim JS, Cho HS, et al. Twenty-eight-day oral toxicity, genotoxicity, and gender-related tissue distribution of silver nanoparticles in Sprague-Dawley rats. Inhal Toxicol. 2008;20(6):575-583.

346. Navarro E, Piccapietra F, Wagner B, et al. Toxicity of silver nanoparticles to Chlamydomonas reinhardtii. Environ Sci Technol. 2008; 42(23):8959-8964.

347. Lu L, Sun RW, Chen R, et al. Silver nanoparticles inhibit hepatitis B virus replication. Antivir Ther. 2008;13(2):253-262.

348. Elechiguerra JL, Burt JL, Morones JR, et al. Interaction of silver nanoparticles with HIV-1. J Nanobiotechnology. 2005;3(1):6.

349. Yeo MK, Yoon JW. Comparison of the effects of nano-silver antibacterial coatings and silver ions on zebrafish embryogenesis. Mol Cell Toxicol. 2009;5(1):23-31.

350. Hussain SM, Hess KL, Gearhart JM, Geiss KT, Schlager JJ. In vitro toxicity of nanoparticles in BRL 3A rat liver cells. Toxicol In Vitro. 2005;19(7):975-983.

351. Sung JH, Ji JH, Yoon JU, et al. Lung function changes in SpragueDawley rats after prolonged inhalation exposure to silver nanoparticles. Inhal Toxicol. 2008;20(6):567-574.

352. Ahamed M, Posgai R, Gorey TJ, Nielsen M, Hussain SM, Rowe JJ. Silver nanoparticles induced heat shock protein 70 , oxidative stress and apoptosis in Drosophila melanogaster. Toxicol Appl Pharmacol. 2010;242(3):263-269.

353. Sims JM. On the treatment of vesico-vaginal fistula. Int Urogynecol J. 1998;9(4):236-248.

354. Schirmer KG. Die Verhütung der Augenentzündung der Neugeborenen [Prevention of Inflammatory Eye Disease in the Newborn]. Berlin: Hirschwald; 1882. German.
355. Silver S, Phung le T, Silver G. Silver as biocides in burn and wound dressings and bacterial resistance to silver compounds. J Ind Microbiol Biotechnol. 2006;33(7):627-634.

356. Feng QL, Wu J, Chen GQ, Cui FZ, Kim TN, Kim JQ. A mechanistic study of the antibacterial effect of silver ions on Escherichia coli and Staphylococcus aureus. J Biomed Mater Res. 2000;52(4):662-668.

357. Guo D, Zhu L, Huang Z, et al. Anti-leukemia activity of PVP-coated silver nanoparticles via generation of reactive oxygen species and release of silver ions. Biomaterials. 2013;34(32):7884-7894.

358. Guo D, Zhao Y, Zhang Y, et al. The cellular uptake and cytotoxic effect of silver nanoparticles on chronic myeloid leukemia cells. J Biomed Nanotechnol. 2014;10(4):669-678.

359. Gurunathan S, Han JW, Eppakayala V, Jeyaraj M, Kim JH. Cytotoxicity of biologically synthesized silver nanoparticles in MDA-MB-231 human breast cancer cells. Biomed Res Int. 2013;2013:535796.

360. Gurunathan S, Raman J, Abd Malek SN, John PA, Vikineswary S. Green synthesis of silver nanoparticles using Ganoderma neo-japonicum Imazeki: a potential cytotoxic agent against breast cancer cells. Int $J$ Nanomedicine. 2013;8:4399-4413.

361. Sahu SC, Zheng J, Graham L, et al. Comparative cytotoxicity of nanosilver in human liver HepG2 and colon Caco2 cells in culture. $J$ Appl Toxicol. 2014;34(11):1155-1166.

362. Foldbjerg R, Dang DA, Autrup H. Cytotoxicity and genotoxicity of silver nanoparticles in the human lung cancer cell line, A549. Arch Toxicol. 2011;85(7):743-750.

363. Nazir S, Hussain T, Iqbal Md MK, Muazzam AG, Ismail JM. Novel and cost-effective green synthesis of silver nano particles and their in vivo antitumor properties against human cancer cell lines. $J$ Biosci Tech. 2011;2(6):425-430.

364. Furno F, Morley KS, Wong B, et al. Silver nanoparticles and polymeric medical devices: a new approach to prevention of infection? J Antimicrob Chemother. 2004;54(6):1019-1024.

365. Matsuura T, Abe Y, Sato Y, Okamoto K, Ueshige M, Akagawa Y. Prolonged antimicrobial effect of tissue conditioners containing silver-zeolite. J Dent. 1997;25(5):373-377.

366. Nikawa H, Yamamoto T, Hamada T, Rahardjo MB, Murata H, Nakanoda S. Antifungal effect of zeolite-incorporated tissue conditioner against Candida albicans growth and/or acid production. J Oral Rehabil. 1997;24(5):350-357.

367. Amendola V, Polizzi S, Meneghetti M. Free silver nanoparticles synthesized by laser ablation in organic solvents and their easy functionalization. Langmuir. 2007;23(12):6766-6770.

368. Navaladian S, Viswanathan B, Varadarajan TK, Viswanath RP. Microwave-assisted rapid synthesis of anisotropic Ag nanoparticles by solid state transformation. Nanotechnology. 2008;19(4):045603.

369. Fernández EJ, García-Barrasa J, Laguna A, López-de-Luzuriaga JM, Monge M, Torres C. The preparation of highly active antimicrobial silver nanoparticles by an organometallic approach. Nanotechnology. 2008;19(18):185602.

370. Thomas V, Yallapu MM, Sreedhar B, Bajpai SK. A versatile strategy to fabricate hydrogel-silver nanocomposites and investigation of their antimicrobial activity. $J$ Colloid Interface Sci. 2007;315(1): 389-395.

371. Kim SH, Choi BS, Kang K, Choi YS, Yang SI. Low temperature synthesis and growth mechanism of Ag nanowires. J Alloys Compounds. 2007;433(1):261-264.

372. Deshmukh RD, Composto RJ. Surface segregation and formation of silver nanoparticles created in situ in poly (methyl methacrylate) films. Chem Mater. 2007;19(4):745-754.

373. Liu JH, Wang AQ, Chi YS, Lin HP, Mou CY. Synergistic effect in an $\mathrm{Au}-\mathrm{Ag}$ alloy nanocatalyst: $\mathrm{CO}$ oxidation. J Phys Chem B. 2005; 109(1):40-43.

374. Ameen KB, Rajasekar K, Rajasekharan T. Silver nanoparticles in mesoporous aerogel exhibiting selective catalytic oxidation of benzene in $\mathrm{CO}_{2}$ free air. Catal Lett. 2007;119(3-4):289-295.

375. Hamal DB, Klabunde KJ. Synthesis, characterization, and visible light activity of new nanoparticle photocatalysts based on silver, carbon, and sulfur-doped $\mathrm{TiO}_{2}$. J Colloid Interface Sci. 2007;311(2):514-522. 
376. Jacob JA, Mahal HS, Biswas N, Mukherjee T, Kapoor S. Role of phenol derivatives in the formation of silver nanoparticles. Langmuir. 2008;24(2):528-533.
377. Jain P, Pradeep T. Potential of silver nanoparticle-coated polyurethane foam as an antibacterial water filter. Biotechnol Bioeng. 2005; 90(1):59-63.

\section{Publish your work in this journal}

The International Journal of Nanomedicine is an international, peerreviewed journal focusing on the application of nanotechnology in diagnostics, therapeutics, and drug delivery systems throughout the biomedical field. This journal is indexed on PubMed Central,

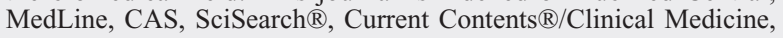

Journal Citation Reports/Science Edition, EMBase, Scopus and the Elsevier Bibliographic databases. The manuscript management system is completely online and includes a very quick and fair peer-review system, which is all easy to use. Visit http://www.dovepress.com/ testimonials.php to read real quotes from published authors. 